\title{
Senescent cells develop a PARP-1 and nuclear factor-kB-associated secretome (PNAS)
}

\author{
Mickaël Ohanna, ${ }^{1,2}$ Sandy Giuliano, ${ }^{1,2}$ Caroline Bonet,${ }^{1,2}$ Véronique Imbert, ${ }^{2,3}$ Véronique Hofman, $, 2,4,5$ \\ Joséphine Zangari, ${ }^{1,2}$ Karine Bille, ${ }^{1,2}$ Caroline Robert, ${ }^{6}$ Brigitte Bressac-de Paillerets, ${ }^{7}$ Paul Hofman, ${ }^{2,4,5}$ \\ Stéphane Rocchi, ${ }^{1,2,8}$ Jean-François Peyron, ${ }^{2,3,9,10}$ Jean-Philippe Lacour, ${ }^{8}$ Robert Ballotti, ${ }^{1,2,8}$ \\ and Corine Bertolotto $1,2,8,11$
}

${ }^{1}$ INSERM, U895, Equipe 1, Biologie et Pathologies des Mélanocytes de la Pigmentation Cutanée au Mélanome, Equipe labellisée Ligue Nationale contre le Cancer, Nice F-06204, France; ${ }^{2}$ Université of Nice Sophia-Antipolis, UFR Médecine, Nice F-06107, France; ${ }^{3}$ INSERM, U895, Equipe 4, Inflammation, Cancer, Cancer Stem Cells, Nice F-06204, France; ${ }^{4}$ INSERM, ERI21/EA 4319, Nice F-06107, France; ${ }^{5}$ Human Biobank, Centre Hospitalier Universitaire de Nice, Nice F-06204, France; ${ }^{6}$ Département de Médecine, Institut de Cancérologie Gustave Roussy, Villejuif Cedex 94805, France; ${ }^{7}$ Département de Biopathologie, Institut de Cancérologie Gustave Roussy, Villejuif Cedex 94805, France; ${ }^{8}$ Service de Dermatologie, Centre Hospitalier Universitaire de Nice, Nice F-06204, France; ${ }^{9}$ Service d'Hématologie, Centre Hospitalier Universitaire de Nice, Nice F-06204, France $;{ }^{10}$ Sevice de Pédiatrie, Centre Hospitalier Universitaire de Nice, Nice F-06204, France

Melanoma cells can enter the process of senescence, but whether they express a secretory phenotype, as reported for other cells, is undetermined. This is of paramount importance, because this secretome can alter the tumor microenvironment and the response to chemotherapeutic drugs. More generally, the molecular events involved in formation of the senescent-associated secretome have yet to be determined. We reveal here that melanoma cells experiencing senescence in response to diverse stimuli, including anti-melanoma drugs, produce an inflammatory secretory profile, where the chemokine ligand-2 (CCL2) acts as a critical effector. Thus, we reveal how senescence induction might be involved in therapeutic failure in melanoma. We further provide a molecular relationship between senescence induction and secretome formation by revealing that the poly(ADP-ribose) polymerase-1 (PARP-1)/nuclear factor-кB (NF-KB) signaling cascade, activated during senescence, drives the formation of a secretome endowed with protumoral and prometastatic properties. Our findings also point to the existence of the PARP-1 and NF-kB-associated secretome, termed the PNAS, in nonmelanoma cells. Most importantly, inhibition of PARP-1 or NF- $\kappa B$ prevents the proinvasive properties of the secretome. Collectively, identification of the PARP-1/NF- $\mathrm{KB}$ axis in secretome formation opens new avenues for therapeutic intervention against cancers.

[Keywords: NF-кB; PARP-1; secretome; senescence; CCL2; invasion]

Supplemental material is available for this article.

Received February 3, 2011; revised version accepted May 12, 2011.

Melanoma cells are well known for their resistance to apoptotic stimuli, likely a remnant of the melanocyte status from which they derive. Indeed, melanocytes have evolved potent anti-apoptotic mechanisms required to resist the mortal effect of ultraviolet radiation constantly reaching the skin, allowing them to achieve their physiologic protective function by synthesizing melanin (Abdel-Malek et al. 2010). Apoptotic resistance represents an important cause that limits the efficacy of the antimelanoma therapies developed so far (Soengas and Lowe 2003; Eberle et al. 2007). In addition to apoptosis, cellular

\footnotetext{
${ }^{11}$ Corresponding author.

E-mail bertolot@unice.fr.

Article published online ahead of print. Article and publication date are online at http://www.genesdev.org/cgi/doi/10.1101/gad.625811.
}

senescence is another important cellular fail-safe mechanism. Ordinarily, senescence is a process arising in normal cells in response to telomere erosion or oncogenic stress, acting through checkpoint activation and cell cycle arrest as a barrier to tumorigenesis (Serrano et al. 1997; Steinert et al. 2000). Activation of checkpoint proteins prevents the replication of genomically instable cells, considered the precursors of transformed cells (Hartwell and Kastan 1994; Elledge 1996). Hence, transformed cells have bypassed the process of senescence. Surprisingly, several lines of evidence indicated recently that cellular senescence remains latently functional and can be reactivated in cancer cells, including melanoma cells /Vance et al. 2005; Zhuang et al. 2008; Giuliano et al. 2011), lending strong support to the use of senescence induction as a therapeutic strategy against melanoma. 
The microphthalmia-associated transcription factor (MITF), in which the M-transcript is specifically expressed in the melanocyte lineage, is critical to melanoma proliferation and survival. MITF stimulates the expression of several genes involved in cell cycle control, invasion, angiogenesis, and anti-apoptotic processes (Cheli et al. 2010). Additionally, MITF is amplified in $\sim 20 \%$ of melanoma cases (Garraway et al. 2005) or lies downstream from several oncogenic signaling pathways such as ETV-1, BRAF ${ }^{\mathrm{V} 600 \mathrm{E}}$, or the EWS-ATF1 fusion (Davis et al. 2006; Wellbrock et al. 2008; JaneValbuena et al. 2010). Cumulatively, these observations have engendered the notion that MITF functions as a melanocyte-specific oncogene, providing an important survival and proliferative advantage to melanoma cells. Consistently, we showed recently that MITF acts as an anti-senescence factor. MITF silencing through activation of the DNA damage response (DDR) pathway triggers senescence-like phenotypes in melanoma cells (Giuliano et al. 2010; Strub et al. 2011).

Senescent cells are growth-arrested, but remain metabolically active and can develop a secretory profile composed mainly of growth factors, cytokines, and proteinases, a typical signature termed the senescence-associated secretory phenotype (SASP) or the senescence messaging secretome (SMS) (Coppe et al. 2008; Kuilman and Peeper 2009). Some of these factors display cell-autonomous activity and work to reinforce the senescence program (Acosta et al. 2008; Kuilman et al. 2008). Other secreted molecules exhibit cellnonautonomous functions associated with inflammation and malignancy and act as protumoral factors (Krtolica et al. 2001; Bavik et al. 2006; Liu and Hornsby 2007). These observations indicate that cellular senescence not only functions as a potent tumor-suppressive process, but may also exhibit deleterious effects. It is an important point to resolve, asinducing senescence in tumor cells is considered a potential therapeutic strategy and some chemotherapeutic drugs function in part through senescence induction (te Poele et al. 2002; Mhaidat et al. 2007). To date, it is not known whether senescent melanoma cells express a secretory phenotype that can alter the behavior of nearby cells. More generally, the molecular events involved in its formation have yet to be determined. Here, we bring evidence that senescent melanoma cells produce a secretome that displays proinvasive and protumorigenic properties. Characterization of this secretome highlights an increased production of proinflammatory factors, among which the chemokine ligand-2 (CCL2) appears as a critical component. Our findings in melanoma and nonmelanoma cells point to a poly/ADPribose) polymerase-1 (PARP-1) and nuclear factor-кB (NF-кB)-associated secretome that we termed PNAS. In melanoma cells, triggering inhibition of PARP-1 or NF$\kappa \mathrm{B}$ prevents CCL2 production and the proinvasive abilities of the PNAS. Altogether, we provide valuable insight into novel potential targets-namely, PARP-1 or NF- $\kappa \mathrm{B}$ - to control the deleterious side effects of cellular senescence.

\section{Results}

Senescent melanoma cells develop a secretome with proinvasive properties

As shown previously, MITF suppression by specific siRNA led to melanoma cell senescence characterized by increased expression in both $\mathrm{p} 27^{\mathrm{KIP} 1}$ and p53 (Fig. 1A) and by senescence-associated $\beta$-galactosidase (SA- $\beta$-Gal) reactivity at $\mathrm{pH} 6$ (Fig. 1B). To determine whether senescent melanoma cells were able to produce an active secretome, naive $501 \mathrm{mel}$ melanoma cells were incubated with the conditioned medium (CM) from 501mel melanoma cells transfected with control or MITF siRNA. When exposed to the CM from senescent melanoma cells, 501mel melanoma cells exhibited a decreased expression of E-cadherin, a marker of epithelial-mesenchymal transition and of MITF (Fig. 1C). Experiments using Matrigel-coated Boyden chambers revealed that the secretome of senescent cells favored invasion of naive $501 \mathrm{mel}$ melanoma cells (Fig. 1D). Altogether, MITF depletion promotes senescence of melanoma cells and triggers the production of a secretory phenotype with proinvasive properties.

We next wished to investigate whether different stimuli-such as oxidative stress, a common inducer of premature senescence, or temozolomide, a chemotherapeutic drug used in melanoma therapy-might also induce senescence and a secretory profile. This was motivated by the observation that $\mathrm{H}_{2} \mathrm{O}_{2}$ or temozolomide decreased the expression of MITF (Supplemental Fig. 1; Mhaidat et al. 2007; Liu et al. 2009). Consistently, we showed that melanoma cells exposed to $\mathrm{H}_{2} \mathrm{O}_{2}$ or temozolomide underwent premature senescence, characterized by flattened and enlarged morphology and by SA- $\beta$-Gal reactivity at $\mathrm{pH} 6$ (Fig. 1E). Noteworthy, we extended these findings to fotemustine, another drug for treating metastatic melanomas. In this context, oxidative stress and chemotherapeutic drugs elicited formation of a secretome that enhanced the invasiveness of melanoma cells (Fig. 1F).

\section{CCL2 is a major actor of the prosurvival and proinvasive function of the secretome}

Data sets from DNA microarray experiments in which the gene profile between control or MITF-silenced melanoma cells were investigated revealed an up-regulation of several secreted factors (Table 1; Supplemental Table S1). Quantitative RT-PCR (qRT-PCR) experiments were also performed on a panel of cytokines reported previously in the secretome of human fibroblasts and epithelial cells (Coppe et al. 2008). In addition to the inhibition of known MITF target genes that validates these experiments, we identified the repertoire of the secretory profile in senescent melanoma cells, demonstrating the presence of growth factors (CTGF and VEGF), proteases (PAI-1 and MMP2), interleukins (IL6), and chemokines (CCL2 and CCL8) (Fig. 2A). Among these, CCL2 appeared as one of the most up-regulated factors. ELISA tests confirmed the increased secretion of CCL2 in the CM of senescent melanoma cells relative to control cells (Fig. 2B). 
A

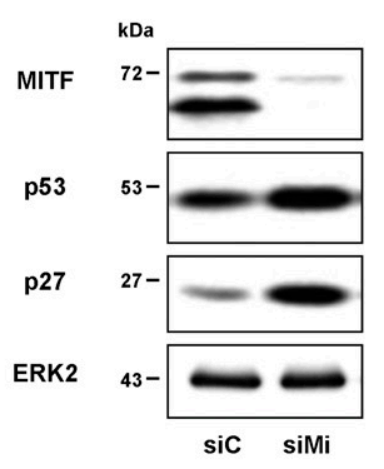

B

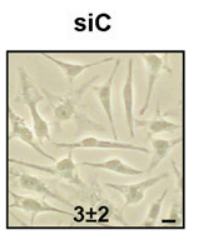

siMi

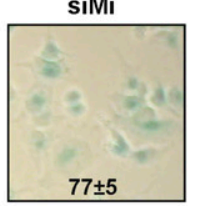

C

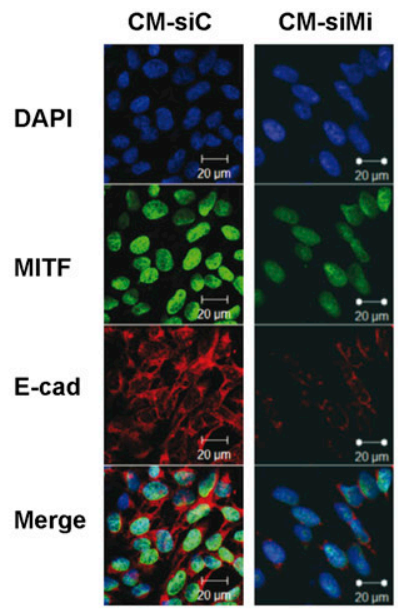

D
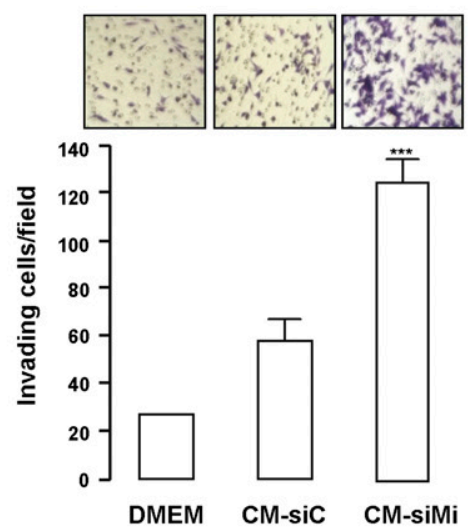
. 
Ohanna et al.

Table 1. cDNA microarray analysis of gene expression changes in MITF-depleted cells compared with control human melanoma cells

\begin{tabular}{|c|c|c|c|c|}
\hline $\begin{array}{l}\text { Gene } \\
\text { symbol }\end{array}$ & $\begin{array}{l}\text { GenBank } \\
\text { (ID) }\end{array}$ & Fold $^{\mathrm{a}}$ & $\pm \mathrm{SD}$ & $P$-value \\
\hline MLANA $^{b}$ & 2315 & -3.396 & 0.00469335 & $8.04713 \times 10^{-6}$ \\
\hline $\mathrm{DCT}^{\mathrm{b}}$ & 1638 & -2.926 & 0.05056096 & $1.09436 \times 10^{-6}$ \\
\hline GPR $143^{b}$ & 4935 & -2.576 & 0.01523909 & $2.04178 \times 10^{-9}$ \\
\hline $\mathrm{CDK}^{\mathrm{b}}$ & 12566 & -2.48 & 0.16978766 & $4.73015 \times 10^{-7}$ \\
\hline MITF $^{\mathrm{b}}$ & 17342 & -2.451 & 0.23248394 & $5.49602 \times 10^{-6}$ \\
\hline $\mathrm{EDNRB}^{\mathrm{b}}$ & 1310 & -2.006 & 0.0601292 & $1.58818 \times 10^{-6}$ \\
\hline TYR $^{\mathrm{b}}$ & 7299 & -1.723 & 0.31832707 & $4.09240 \times 10^{-6}$ \\
\hline TYMS & 7298 & -1.422 & 0.08074477 & $9.72427 \times 10^{-7}$ \\
\hline TLR4 & 7099 & -0.933 & 0.03433735 & $1.23108 \times 10^{-3}$ \\
\hline GAS1 & 2619 & -0.811 & 0.12216614 & $1.39045 \times 10^{-4}$ \\
\hline CSF1 & 1435 & -0.371 & 0.04441918 & $2.13012 \times 10^{-5}$ \\
\hline MMP2 & 17390 & -0.363 & 0.05642465 & $9.02718 \times 10^{-3}$ \\
\hline MMP19 & 4327 & -0.343 & 0.09860566 & $8.92820 \times 10^{-4}$ \\
\hline IL23A & 51561 & -0.269 & 0.12139847 & $2.02080 \times 10^{-4}$ \\
\hline PLCD3 & 113026 & -0.258 & 0.05592975 & $1.52767 \times 10^{-2}$ \\
\hline IL1B & 3553 & -0.244 & 0.03340169 & $3.48169 \times 10^{-2}$ \\
\hline CCL20 & 6364 & -0.243 & 0.00974077 & $3.14077 \times 10^{-2}$ \\
\hline CCR2 & 729230 & -0.236 & 0.19877822 & $3.61513 \times 10^{-2}$ \\
\hline IL12B & 3563 & -0.213 & 0.07021685 & $1.88224 \times 10^{-2}$ \\
\hline MMP24 & 10893 & -0.213 & 0.12310318 & $8.05570 \times 10^{-2}$ \\
\hline PLA2G2A & 5320 & -0.213 & 0.04219609 & $8.68977 \times 10^{-3}$ \\
\hline MMP3 & 4314 & -0.195 & 0.09721145 & $8.19207 \times 10^{-2}$ \\
\hline IFNG & 3458 & -0.188 & 0.11872011 & $6.98492 \times 10^{-2}$ \\
\hline CCL23 & 6368 & -0.185 & 0.08916862 & $6.63650 \times 10^{-2}$ \\
\hline TK1 & 21877 & -0.184 & 0.05639935 & $1.08145 \times 10^{-3}$ \\
\hline MMP25 & 64386 & -0.175 & 0.03900126 & $8.54730 \times 10^{-3}$ \\
\hline CXCL2 & 20310 & -0.149 & 0.03691421 & $4.66324 \times 10^{-3}$ \\
\hline IL25 & 64806 & -0.142 & 0.04799052 & $3.00527 \times 10^{-2}$ \\
\hline CCL13 & 6357 & -0.141 & 0.04416873 & $8.25103 \times 10^{-2}$ \\
\hline MMP27 & 64066 & -0.136 & 0.03272653 & $5.93853 \times 10^{-2}$ \\
\hline CXCL13 & 10563 & -0.135 & 0.09607781 & $4.14763 \times 10^{-2}$ \\
\hline LTA & 4049 & -0.134 & 0.00088346 & $5.49827 \times 10^{-2}$ \\
\hline CCL1 & 6346 & -0.129 & 0.02817 & $2.88115 \times 10^{-2}$ \\
\hline NOS2A & 4843 & -0.128 & 0.00096244 & $4.89411 \times 10^{-2}$ \\
\hline TNC & 3371 & -0.125 & 0.10351928 & $1.78136 \times 10^{-3}$ \\
\hline CSF3 & 1440 & -0.121 & 0.03524244 & $1.39775 \times 10^{-1}$ \\
\hline CTSW & 1521 & -0.118 & 0.01530317 & $1.31139 \times 10^{-2}$ \\
\hline IL20 & 50604 & -0.114 & 0.04449025 & $3.45001 \times 10^{-2}$ \\
\hline CTSD & 1509 & -0.108 & 0.11152328 & $2.56195 \times 10^{-2}$ \\
\hline MMP28 & 79148 & -0.106 & 0.10373071 & $9.15194 \times 10^{-2}$ \\
\hline PTGS1 & 5742 & -0.106 & 0.08950215 & $1.60982 \times 10^{-1}$ \\
\hline COL4A6 & 1288 & -0.103 & 0.04429363 & $5.36657 \times 10^{-2}$ \\
\hline MMP12 & 17381 & -0.103 & 0.0940134 & $1.31296 \times 10^{-1}$ \\
\hline NRG1 & 3084 & -0.102 & 0.00229363 & $73 \times 10^{-2}$ \\
\hline IL26 & 55801 & -0.091 & 0.12030261 & $27 \times 10^{-2}$ \\
\hline CCL21 & 6366 & -0.089 & 0.0462948 & $1.37405 \times 10^{-1}$ \\
\hline CDKN1A & 1026 & -0.087 & 0.00241119 & $3.63617 \times 10^{-2}$ \\
\hline CXCL16 & 58191 & -0.079 & 0.04920185 & $9.57840 \times 10^{-2}$ \\
\hline CXCL6 & 6373 & -0.079 & 0.05563248 & $7.44885 \times 10^{-2}$ \\
\hline TNF & 7124 & -0.076 & 0.10599916 & $2.04133 \times 10^{-2}$ \\
\hline CCL15 & 6359 & -0.074 & 0.1840475 & $2.67800 \times 10^{-1}$ \\
\hline IL22 & 50616 & -0.069 & 0.04443437 & $4.70844 \times 10^{-2}$ \\
\hline CTSF & 8722 & -0.064 & 0.17873298 & $7.44832 \times 10^{-2}$ \\
\hline CCL17 & 6361 & -0.06 & 0.02860028 & $1.06012 \times 10^{-2}$ \\
\hline CCL25 & 6370 & -0.06 & 0.03206517 & $8.95740 \times 10^{-2}$ \\
\hline CXCL3 & 2921 & -0.056 & 0.05773861 & $1.08537 \times 10^{-1}$ \\
\hline STC1 & 6781 & -0.055 & 0.08652515 & $3.29925 \times 10^{-2}$ \\
\hline ICAM2 & 3384 & -0.05 & 0.034037 & $6.85285 \times 10^{-2}$ \\
\hline BMP4 & 652 & -0.047 & 0.16797378 & $9.09294 \times 10^{-2}$ \\
\hline
\end{tabular}

\begin{tabular}{|c|c|c|c|c|}
\hline $\begin{array}{l}\text { Gene } \\
\text { symbol }\end{array}$ & $\begin{array}{l}\text { GenBank } \\
\text { (ID) }\end{array}$ & Fold $^{\mathrm{a}}$ & $\pm \mathrm{SD}$ & $P$-value \\
\hline IL-O & 3578 & -0.04 & 0.12030261 & $2.09212 \times 10^{-2}$ \\
\hline IL10 & 3586 & -0.039 & 0.28276301 & $3.87999 \times 10^{-2}$ \\
\hline MMP1 & 4312 & -0.039 & 0.03421012 & $3.22879 \times 10^{-2}$ \\
\hline CXCL9 & 4283 & -0.031 & 0.13624919 & $3.95013 \times 10^{-2}$ \\
\hline MIA & 8190 & -0.028 & 0.13349621 & $2.37235 \times 10^{-2}$ \\
\hline MMP13 & 4322 & -0.027 & 0.03293029 & $2.68117 \times 10^{-2}$ \\
\hline MMP25 & 64386 & -0.024 & 0.07126598 & $1.16738 \times 10^{-1}$ \\
\hline CXCL5 & 6374 & -0.023 & 0.05766034 & $1.92241 \times 10^{-1}$ \\
\hline ICAM4 & 3386 & -0.021 & 0.0602564 & $5.32837 \times 10^{-2}$ \\
\hline ICAM5 & 7087 & -0.021 & 0.01765933 & $6.90036 \times 10^{-2}$ \\
\hline CTSG & 1511 & -0.019 & 0.04826551 & $3.04112 \times 10^{-2}$ \\
\hline GADD45G & 10912 & -0.018 & 0.01332963 & $7.77610 \times 10^{-3}$ \\
\hline CCL19 & 6363 & -0.017 & 0.02546197 & $5.19356 \times 10^{-2}$ \\
\hline CTSG & 1511 & -0.017 & 0.03127073 & $1.40399 \times 10^{-2}$ \\
\hline CSF2 & 1437 & -0.016 & 0.19010607 & $1.15334 \times 10^{-1}$ \\
\hline $\mathrm{CDH} 2$ & 1000 & -0.013 & 0.14005396 & $1.17865 \times 10^{-1}$ \\
\hline PTGDS & 5730 & -0.013 & 0.03829708 & $5.72295 \times 10^{-2}$ \\
\hline CXCL12 & 6387 & -0.007 & 0.0534576 & $4.61921 \times 10^{-2}$ \\
\hline CXCL2 & 2920 & -0.007 & 0.01285506 & $3.68607 \times 10^{-2}$ \\
\hline CCL16 & 6360 & -0.004 & 0.07659257 & $1.31388 \times 10^{-1}$ \\
\hline LTB & 4050 & -0.003 & 0.06626507 & $8.08394 \times 10^{-2}$ \\
\hline CCL8 & 6355 & 0.001 & 0.009756 & $8.70336 \times 10^{-2}$ \\
\hline IL18 & 3606 & 0.001 & 0.08638869 & $9.49701 \times 10^{-3}$ \\
\hline RELB & 5971 & 0.009 & 0.072504 & $3.94405 \times 10^{-2}$ \\
\hline CCL22 & 6367 & 0.01 & 0.05544205 & $4.56941 \times 10^{-2}$ \\
\hline CTSO & 1519 & 0.011 & 0.08053704 & $1.00937 \times 10^{-1}$ \\
\hline $\mathrm{CTSH}$ & 1512 & 0.012 & 0.03064311 & $6.75132 \times 10^{-4}$ \\
\hline CCL24 & 6369 & 0.013 & 0.10769452 & $8.66071 \times 10^{-2}$ \\
\hline VCAM1 & 7412 & 0.051 & 0.07163438 & $8.55584 \times 10^{-2}$ \\
\hline IGFBP5 & 3488 & 0.052 & 0.10329463 & $8.90928 \times 10^{-2}$ \\
\hline CTSK & 1513 & 0.053 & 0.01863409 & $5.06492 \times 10^{-4}$ \\
\hline IGFBP4 & 3487 & 0.059 & 0.03129747 & $1.93127 \times 10^{-2}$ \\
\hline IL9 & 3578 & 0.063 & 0.10903487 & $1.40012 \times 10^{-2}$ \\
\hline PLAUR & 5329 & 0.063 & 0.05902043 & $1.37965 \times 10^{-1}$ \\
\hline FN1 & 2335 & 0.074 & 0.07163438 & $9.83550 \times 10^{-3}$ \\
\hline IL21 & 59067 & 0.074 & 0.05101306 & $6.08349 \times 10^{-2}$ \\
\hline MMP9 & 4318 & 0.0 & 0.0 & $7 \times 10^{-1}$ \\
\hline MMP10 & 4319 & 0.092 & 0.04333 & $1.40480 \times 10^{-1}$ \\
\hline TGFB3 & 25717 & 0.098 & 0.05451782 & $2.38719 \times 10^{-2}$ \\
\hline IGFBP1 & 3484 & 0.102 & 0.06091146 & $2.41393 \times 10^{-2}$ \\
\hline CXCL1 & 2919 & 0.106 & 0.05529325 & $1.10330 \times 10^{-1}$ \\
\hline CCL26 & 10344 & 0.109 & 0.07018633 & $1.84028 \times 10^{-2}$ \\
\hline MMP11 & 4320 & 0.109 & 0.0335571 & $1.10855 \times 10^{-2}$ \\
\hline MMP7 & 4316 & 0.109 & 0.11580969 & $2.74066 \times 10^{-2}$ \\
\hline TNFRSF9 & 3604 & 0.118 & 0.08760524 & $5.28789 \times 10^{-2}$ \\
\hline IL29 & 282618 & 0.121 & 0.01351721 & $3.46559 \times 10^{-2}$ \\
\hline IFNA21 & 3452 & 0.123 & 0.1656126 & $1.65385 \times 10^{-1}$ \\
\hline CCL28 & 56477 & 0.135 & 0.01215404 & $1.30217 \times 10^{-2}$ \\
\hline CCL7 & & 0.154 & 0.05752267 & $62 \times 10^{-1}$ \\
\hline ICAM3 & 3385 & 0.154 & 0.03228226 & $4.22483 \times 10^{-3}$ \\
\hline CXCL11 & 6373 & 0.156 & 0.02812627 & $1.06364 \times 10^{-2}$ \\
\hline SERPINE2 & 5270 & 0.157 & 0.10468166 & $1.36530 \times 10^{-3}$ \\
\hline FLT3LG & 2323 & 0.159 & 0.04443621 & $6.00479 \times 10^{-2}$ \\
\hline BTC & 685 & 0.16 & 0.00355782 & $6.76506 \times 10^{-2}$ \\
\hline CSF3R & 1441 & 0.175 & 0.07321103 & $9.66746 \times 10^{-2}$ \\
\hline CTSC & 1075 & 0.182 & 0.02526494 & $3.18481 \times 10^{-3}$ \\
\hline JUNB7 & 3726 & 0.187 & 0.01970141 & $3.72137 \times 10^{-2}$ \\
\hline VIM & 7431 & 0.187 & 0.03228226 & $4.24392 \times 10^{-5}$ \\
\hline
\end{tabular}


Table 1. Continued

\begin{tabular}{|c|c|c|c|c|}
\hline $\begin{array}{l}\text { Gene } \\
\text { symbol }\end{array}$ & $\begin{array}{l}\text { GenBank } \\
\text { (ID) }\end{array}$ & Fold $^{\mathrm{a}}$ & $\pm \mathrm{SD}$ & $P$-value \\
\hline HSPA6 & 3310 & 0.194 & 0.13625277 & $8.48267 \times 10^{-2}$ \\
\hline LSP1 & 4046 & 0.195 & 0.00634355 & $2.23926 \times 10^{-2}$ \\
\hline FGF12 & 2257 & 0.207 & 0.01286341 & $2.90329 \times 10^{-3}$ \\
\hline COL9A2 & 1298 & 0.211 & 0.04611897 & $8.41449 \times 10^{-2}$ \\
\hline IER3 & 8870 & 0.216 & 0.11462237 & $8.39038 \times 10^{-3}$ \\
\hline FGF1 & 2246 & 0.222 & 0.13785331 & $2.36248 \times 10^{-1}$ \\
\hline HDGF & 3068 & 0.235 & 0.23390925 & $1.15897 \times 10^{-1}$ \\
\hline MST1 & 4485 & 0.235 & 0.08689901 & $8.38854 \times 10^{-2}$ \\
\hline TNFRSF11B & 4982 & 0.238 & 0.01981589 & $1.03923 \times 10^{-1}$ \\
\hline NFKB2 & 4791 & 0.246 & 0.13918396 & $4.92325 \times 10^{-4}$ \\
\hline SERPINE1 & 5054 & 0.255 & 0.07002693 & $7.47856 \times 10^{-2}$ \\
\hline AGT & 183 & 0.263 & 0.04780101 & $2.39202 \times 10^{-1}$ \\
\hline MIF & 4282 & 0.278 & 0.03198065 & $2.45980 \times 10^{-1}$ \\
\hline IL11 & 3589 & 0.296 & 0.08402775 & $2.16209 \times 10^{-1}$ \\
\hline NGFR & 4808 & & 0.0206 & $1.41731 \times 1$ \\
\hline FGFR4 & 2264 & 0.309 & 0.02807424 & $3.49911 \times 10^{-2}$ \\
\hline AGGF1 & 55109 & 0.312 & 0.00700683 & $4.61616 \times 10^{-3}$ \\
\hline SMAD7 & 4092 & 0.331 & 0.119600 & $5.86286 \times 1$ \\
\hline IL6 & 3569 & 0.367 & 0.07163438 & $1.01234 \times 10^{-1}$ \\
\hline IGFBP6 & 3489 & 0.383 & 0.06735018 & $1.75374 \times 10^{-1}$ \\
\hline IL27 & 246778 & 0.392 & 0.0212541 & $5.80652 \times 10^{-3}$ \\
\hline VEGFC & 7424 & 0.413 & 0.01907472 & $7.23867 \times 10^{-2}$ \\
\hline TRAF2 & 7186 & 0.416 & 0.10388079 & $5.51054 \times 10^{-2}$ \\
\hline CCL4 & 6351 & 0.417 & 0.03471908 & $2.18954 \times 10^{-1}$ \\
\hline SDC4 & & 0.427 & 0.02426495 & $1.91047 \times 10^{-2}$ \\
\hline PDGFD & 803 & & & $4.34758 \times 10^{-3}$ \\
\hline COL2A & 1280 & & & $9.03650 \times 1$ \\
\hline BMP6 & 654 & 0.4 & 0.00 & $1.26776 \times 10^{-1}$ \\
\hline TNFRSF1A & 7132 & 0.527 & 0.0427 & $3.09261 \times 10^{-2}$ \\
\hline SOD1 & 6647 & 0.529 & 0.04 & $2.60945 \times 1$ \\
\hline FAM14B & 122509 & 0.532 & 0.05758841 & $1.59962 \times 10^{-2}$ \\
\hline CTSZ & 1522 & 0.547 & 0.0574 & $1.15803 \times 10^{-1}$ \\
\hline TRAF3IP1 & 26146 & 0.5 & 0.00586068 & $3.16481 \times 10^{-1}$ \\
\hline BIRC2 & 329 & 0.563 & 0.02167024 & $6.14313 \times 10^{-2}$ \\
\hline HDGF2 & 84717 & 0.621 & 0.00114578 & $8.22141 \times 10^{-2}$ \\
\hline LAMB2 & 3913 & 0.622 & 0.01686728 & $8.89489 \times 10^{-2}$ \\
\hline TIMP1 & 7076 & 0.6 & 0.0271 & $1.04885 \times 10^{-1}$ \\
\hline IGFBP3 & 348 & & & $0^{-1}$ \\
\hline IL16 & & & & $0^{-1}$ \\
\hline IL24 & 11009 & 0.6 & 0.1 & $5.60773 \times 10^{-1}$ \\
\hline PDGFB & & 0.695 & 0.11205684 & $2.06073 \times 10^{-1}$ \\
\hline CTSB & 1508 & 0.699 & 0.141 & $93 \times 10^{-1}$ \\
\hline GADD45A & 1647 & 0.712 & 0.10124251 & $3.77788 \times 10^{-2}$ \\
\hline SEMA4B & 10509 & 0.84 & 0.18886948 & $3.23612 \times 10^{-1}$ \\
\hline ITGB1 & 16412 & 0.847 & 0.06665488 & $2.66585 \times 10^{-1}$ \\
\hline PDE2A & 5138 & 1.133 & 0.02905928 & $1.51422 \times 10^{-1}$ \\
\hline BDNF & 627 & 1.146 & 0.05858526 & $3.98007 \times 10^{-1}$ \\
\hline CTGF & 1490 & 1.244 & 0.14782365 & $1.77277 \times 10^{-4}$ \\
\hline IGFBP7 & & & & $1.37238 \times 10^{-1}$ \\
\hline PTGS2 & 5743 & 1.285 & 0.07504039 & $0^{-1}$ \\
\hline $\mathrm{AMH}$ & & 1.336 & 0.06635736 & $1.24572 \times 10^{-1}$ \\
\hline PLAT & 5327 & 1.43 & 0.26339494 & $2.59806 \times 10^{-1}$ \\
\hline TNFRSF10B & 8795 & 1.457 & 0.03303672 & $1.39879 \times 10^{-2}$ \\
\hline NQO1 & 1728 & 1.475 & 0.06055538 & $6.16143 \times 10^{-3}$ \\
\hline CSK & 1445 & 1.488 & 0.0175709 & $3.98390 \times 10^{-2}$ \\
\hline ITGB5 & 3693 & 1.52 & 0.09783993 & $3.09931 \times 10^{-4}$ \\
\hline SEMA3B & 7869 & 1.53 & 0.03051046 & $4.88247 \times 10^{-4}$ \\
\hline TNFRSF12A & 51330 & 1.631 & 0.12770329 & $4.47505 \times 10^{-3}$ \\
\hline GADD45B & & & & $5.43204 \times 10^{-4}$ \\
\hline IGFBP2 & 3485 & 1.841 & 0.09972546 & $3.62513 \times 10^{-2}$ \\
\hline
\end{tabular}

\begin{tabular}{lrrll}
\hline $\begin{array}{l}\text { Gene } \\
\text { symbol }\end{array}$ & $\begin{array}{c}\text { GenBank } \\
(\mathrm{ID})\end{array}$ & Fold $^{\mathrm{a}}$ & \multicolumn{1}{c}{ \pm SD } & $P$-value \\
\hline TGFBI & 7045 & 1.912 & 0.00266754 & $2.90498 \times 10^{-2}$ \\
COL9A3 & 1299 & 1.913 & 0.22407717 & $2.16665 \times 10^{-3}$ \\
PAM & 5066 & 2.003 & 0.03775165 & $2.15620 \times 10^{-4}$ \\
PLA2G4A & 5321 & 2.006 & 0.05901066 & $6.02372 \times 10^{-5}$ \\
TNFRSF21 & 27242 & 2.019 & 0.12051874 & $5.90708 \times 10^{-4}$ \\
IGFBP5 & 3488 & 2.021 & 0.0169905 & $6.03683 \times 10^{-3}$ \\
CXCL14 & 9547 & 2.832 & 0.01878546 & $3.51887 \times 10^{-4}$ \\
CEBPD & 1052 & 3.294 & 0.11188847 & $1.44954 \times 10^{-5}$ \\
CCL2 & 6347 & 3.326 & 0.0137319 & $4.03017 \times 10^{-6}$ \\
CYR61 & 3491 & 3.644 & 0.13448109 & $1.37916 \times 10^{-7}$ \\
\hline
\end{tabular}

${ }^{\mathrm{a}}$ The ratio results (siMi/siC) are expressed as the mean $\pm \mathrm{SD}$ of $\log 2$ fold values. We pooled the raw data from two siC and two different MITF siRNA (siMil and siMi2).

${ }^{\mathrm{b}}$ Previously reported MITF target genes (Cheli et al. 2010).

The effect of MITF silencing on increased CCL2 mRNA and secretion was counteracted by restoring MITF expression, thereby ruling out a nonspecific effect of siRNA (Supplemental Fig. S2). The Boyden chamber experiments showed that CCL2 stimulated the invasive capability of naive 501 mel melanoma cells, while an antiCCL2-neutralizing antibody almost completely abolished this function (Fig. 2C). CCL2 secretion was also strongly increased in the secretome of melanoma cells exposed to oxidative stress or chemotherapeutic drugs (Fig. 2D). Interestingly, the CM of senescent melanoma cells or CCL2 also promoted DNA lesions, as illustrated by an increase in 53BP1 foci (Supplemental Fig. S3a). These DNA lesions were milder than those evoked by $\mathrm{H}_{2} \mathrm{O}_{2}$ exposure. Furthermore, a blockade of staurosporine proapoptotic effects by the secretome of senescent melanoma cells or CCL2 was also observed, as shown by the inhibition of PARP-1 cleavage (Supplemental Fig. S3b) and the decrease in the nonviable DAPI-positive cells (Supplemental Fig. S3c). In all, these results demonstrate that melanoma cells undergoing senescence develop a secretome with protumoral and proinvasive properties in which the chemokine CCL2 is a critical factor.

The secretome from senescent melanoma cells or CCL2 confers in vivo metastatic properties

To determine the effect of the secretome in vivo, the model of $501 \mathrm{mel}$ human melanoma cells was chosen because $501 \mathrm{mel}$ cells do not grow as xenografts into athymic nude mice. We found that tumors formed when $501 \mathrm{mel}$ cells were exposed in vitro to the CM from senescent cells (seven out of eight xenografts) or to recombinant CCL2 (Fig. 3A,B). In contrast, no tumors grew when 501mel cells were exposed to the CM from control proliferative cells (zero out of eight xenografts).

To evaluate whether the increase in the in vitro invasive ability translated into augmented metastatic potential, we tested the capacity of $501 \mathrm{mel}$ cells exposed to the CM recombinant CCL2 to form lung metastases in vivo. Histological examination (hematoxylin and eosin [H\&E] staining) showed that, although no tumor was 
Ohanna et al.
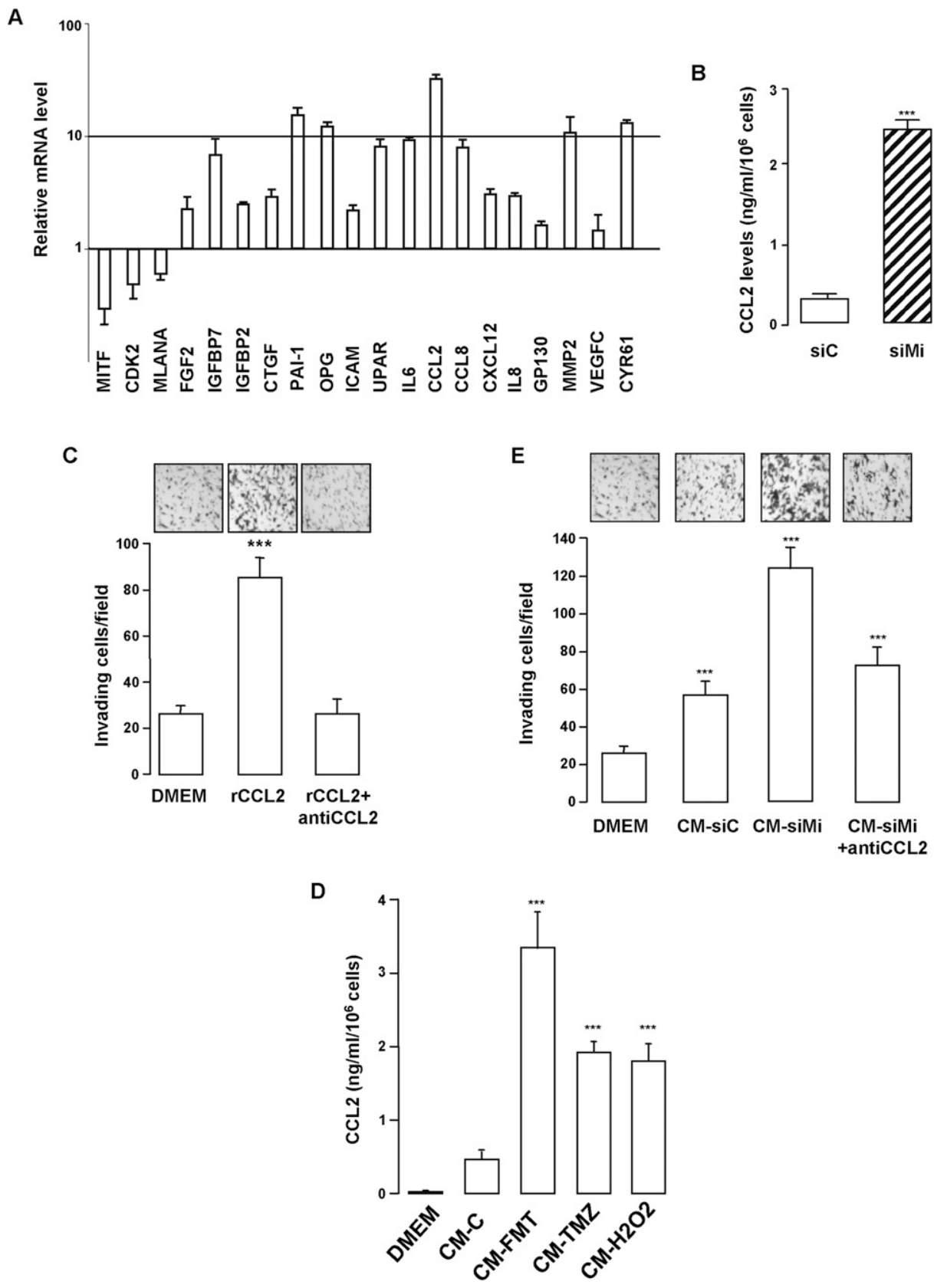

Figure 2. CCL2 is a major determinant of the secretome. (A) RNAs were harvested from control (siC) or MITF (siMi) siRNA for $96 \mathrm{~h}$ and were assayed by qRT-PCR for transcripts indicated on the figure. Transcript levels are represented relative to those found in control-transfected cells as mean $+\mathrm{SD}$. The results in the graph are expressed as log2 values. (B) ELISA test of CCL2 levels in the CM of control (CM-siC) or senescent (CM-siMi) 501mel melanoma cells. Data, represented as mean $+\mathrm{SD}$, are significantly different; $\left({ }^{\star \star \star}\right) P<$ 0.001. (C) The chemotactic effect of recombinant CCL2 $(100 \mathrm{ng} / \mathrm{mL})$ with or without anti-human CCL2-neutralizing antibody (100 $\mu \mathrm{g} / \mathrm{mL}$ ) was tested on naive $501 \mathrm{mel}$ melanoma cells in Boyden chambers, and the number of nuclei was counted using NIH Image analysis software. The average values from three experiments + SD are shown. Significantly different at $P<0.001\left(^{\star \star \star}\right)$. Representative images are shown. (D) $501 \mathrm{mel}$ cells were left untreated (CM-C) or were exposed to fotemustine (FMT, $40 \mathrm{mM})$, temozolomide (TMZ, $900 \mathrm{nM})$ or $\mathrm{H}_{2} \mathrm{O}_{2}(100 \mu \mathrm{M})$ for $96 \mathrm{~h}$. CCL2 secretion levels were analyzed by ELISA. Values are expressed as mean + SD. $(E)$ The chemotactic effect of control (CM-siC) or senescent (CM-siMi) cells, supplemented or not with anti-human CCL2-neutralizing antibody $(100 \mu \mathrm{g} / \mathrm{mL})$, was assessed on naive $501 \mathrm{mel}$ cells. The number of nuclei was counted using NIH ImageJ analysis software. Values are expressed as mean $+\mathrm{SD}$. Significantly different at $P<0.001\left(^{\star \star \star}\right)$. Representative images are shown.

detectable in the lungs of the mice injected with the 501 mel cells exposed to the control CM, melanoma lung metastases were found when $501 \mathrm{mel}$ cells were previ- ously exposed to the CM of senescent melanoma cells or to recombinant CCL2 (Fig. 3C). S100 immunolabeling confirmed the presence of melanoma lung metastases. It 
A

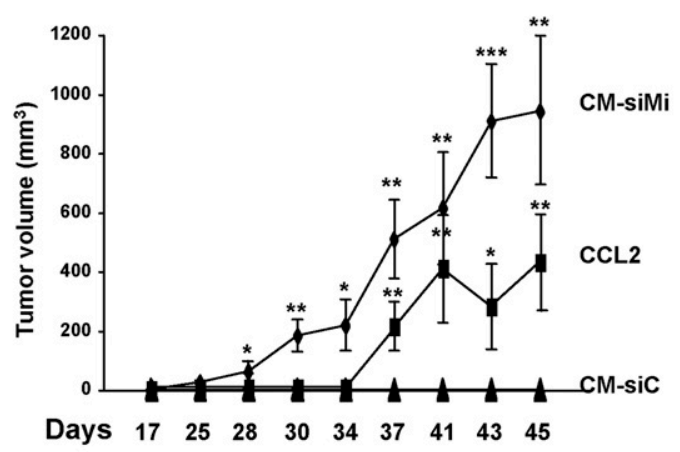

C

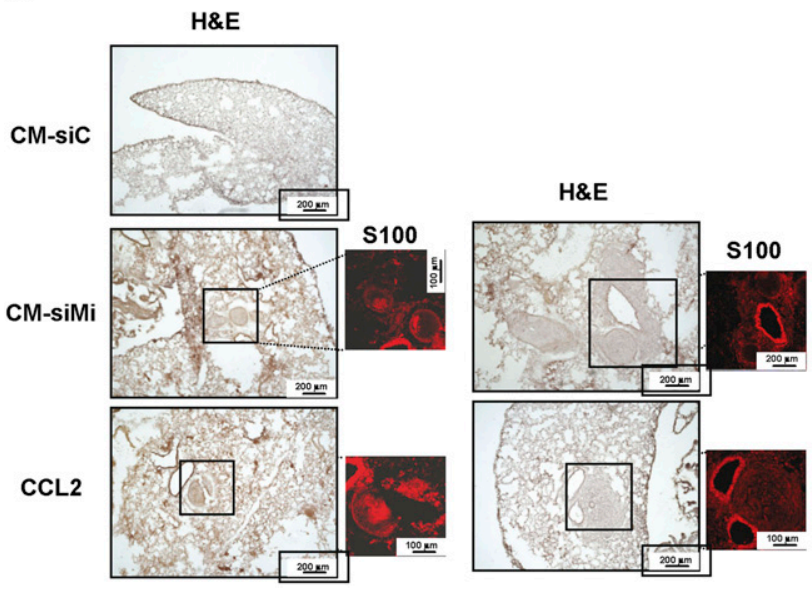

B

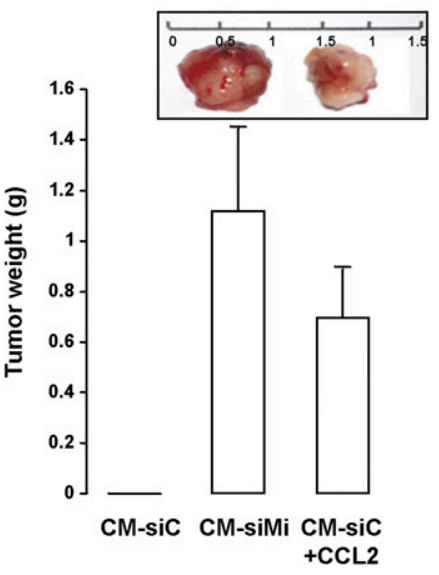

D

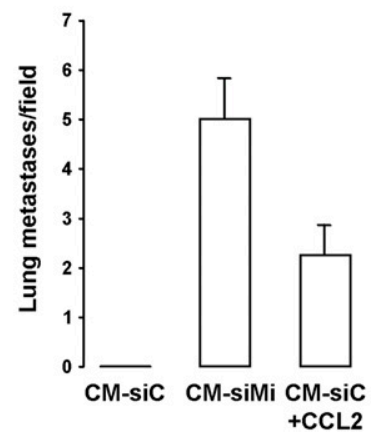

Figure 3. The secretome from senescent cells or recombinant CCL 2 confers tumor properties. $(A) 501$ mel melanoma cells $\left(4 \times 10^{6}\right)$ were exposed in vitro to the CM from control or senescent melanoma cells or to recombinant CCL2, and next were subcutaneously engrafted in athymic nude mice. Tumors were measured at the time indicated on the figure. Kinetics of tumor growth are shown as mean $( \pm \mathrm{SEM})$ tumor volume (square millimeters). Two-tailed Student's $t$-test: $\left({ }^{\star}\right) P=0.05 ;\left(^{\star \star}\right) P=0.01 ;\left(^{\star \star \star}\right) P=0.001$. $(B)$ Weight of the excised tumors. Representative tumors at $45 \mathrm{~d}$ are shown. $(C) 501 \mathrm{mel}$ melanoma cells $\left(4 \times 10^{6}\right)$ were injected in the dorsal tail vein of athymic nude mice. Forty-five days later, mice were sacrificed and the lungs were excised. Fixed lungs were serially sectioned and stained with H\&E or DAPI and immunostained for S100. Representative H\&E- and S100-labeled sections of each condition are shown. $(D)$ Quantitative evaluation of metastatic lesions by a number of 501 mel lung colonies expressed by field (five fields counted) + SD.

is noteworthy that $\mathrm{S} 100$ immunoreactivity was absent in normal tissue, but can be observed in basal cells of the bronchial epithelium, typically in the inflamed areas near invading tumor cells, as reported previously (Matsubara et al. 2005). The quantitative analyses of lung sections revealed the significant increase in the number of $501 \mathrm{mel}$ lung metastases in the two later conditions relative to cells exposed to the CM of proliferative melanoma cells (Fig. 3D). Collectively, the secretome from senescent melanoma cells and CCL2 also confer tumor and metastatic properties in vivo.

The NF-кB signaling pathway controls formation of the senescence-associated secretome

It is noteworthy that the secretome comprises several proinflammatory factors, prompting us to envision an involvement of the NF-кB signaling pathway in its formation. NF- $\mathrm{BB}$ is present as a latent, inactive cytoplasmic form, while activated NF- $\mathrm{B}$ is translocated into the nucleus, where it binds to specific $\kappa \mathrm{B}$ enhancer elements in the promoter of its target genes. First, we investigated by immunofluorescence experiments the cellular localization of the p65/RELA subunit of NF- $\mathrm{kB}$. In control conditions, p65/RELA localized mainly to the cytoplasm, while, in response to $\mathrm{TNF} \alpha$, a known stimulator of NF- $\mathrm{B}$ activity, p65/RELA relocalized to the nucleus (Supplemental Fig. 4a). Interestingly, a massive nuclear accumulation of p65/RELA, stronger than that induced by $\mathrm{TNF} \alpha$ exposure, was also observed in melanoma cells experiencing senescence upon MITF depletion (Fig. 4A). Immunohistochemistry on human melanoma samples revealed a heterogenous staining for both p65/RELA and MITF (Fig. 4B). However, cytoplasmic p65/RELA was 
Ohanna et al.
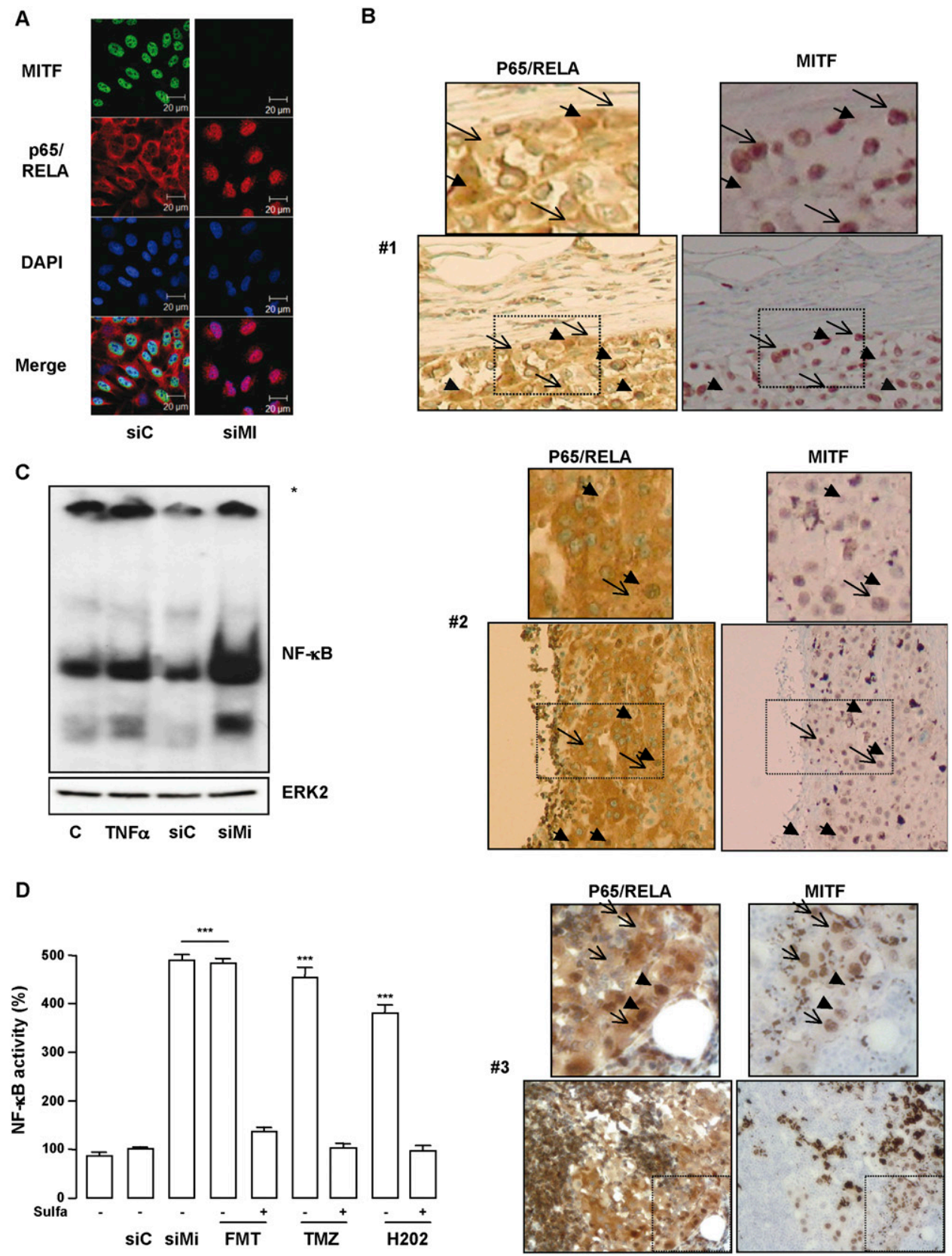

Figure 4. Stimulation of NF-кB activity in senescent cells. (A) Immunofluorescent staining with p65/RELA (red) and MITF (green) of $501 \mathrm{mel}$ cells transfected with siC or siMi for $96 \mathrm{~h}$. (B) Immunohistochemical analysis of three human melanoma metastases (\#1, $\# 2$, and \#3) using antibodies to p65/RELA and MITF. Insets show high magnification. ( $C$, top panel) EMSA experiment of siC or siMi transfected $501 \mathrm{mel}$ cells for $96 \mathrm{~h}$. Asterisk indicates the protein:DNA complexes remain trapped at the bottom of the gel. (Bottom panel) Western blot analysis of the same cell extracts revealed no change in ERK2 levels. (D) NF-кB luciferase promoter activity of $501 \mathrm{mel}$ cells transfected with MITF siRNA or exposed to fotemustine (FMT, $40 \mathrm{mM}$ ), temozolomide (TMZ, $900 \mathrm{nM}$ ), or $\mathrm{H}_{2} \mathrm{O}_{2}(100 \mu \mathrm{M})$ in the presence or absence of sulfasalazine $(500 \mu \mathrm{M})$. Results are expressed as percent (\%) + SD of the luciferase activity from the control condition. Significantly different from control at $P<0.001\left(^{\star \star \star}\right)$.

observed in cells with strong nuclear MITF staining, while nuclear p65/RELA was associated with low/absent nuclear MITF staining. In agreement with the immunofluorescences, electrophoretic mobility shift assay (EMSA) revealed a stronger NF- $\mathrm{kB}$ binding in MITFdepleted $501 \mathrm{mel}$ cells compared with control or TNF $\alpha$ - treated cells (Fig. 4C). A cell-based luciferase reporter assay confirmed that MITF depletion increased the transcriptional activity of NF- $\mathrm{kB}$ (Fig. 4D). Furthermore, oxidative stress and the chemotherapeutic drugs also stimulated, in a similar range, the transcriptional activity of NF- $\mathrm{kB}$ that was impaired in the presence of sulfasalazine, 
a NF-кB inhibitor. Hence, secretome formation by senescent cells is associated with stimulation of the transcriptional activity of NF- $\mathrm{kB}$.

\section{NF- $\kappa B$ controls CCL2 secretion and the invasive properties of the secretome}

Having shown that senescent melanoma cells produce a secretome and display an increased NF-кB activity, we next thought to determine the role of NF-кB in its formation. qRT-PCR (Fig. 5A) and ELISA (Fig. 5B) showed a stimulation of both CCL2 mRNA levels and CCL2 secretion, respectively, in MITF silenced cells relative to control cells that were impaired by genetic (IKK2 siRNA) or pharmacological (sulfasalazine) inhibition of NF-кB. Furthermore, blocking NF- $\mathrm{B}$ prevented the proinvasive effect of the secretome (Fig. 5C). NF- $\mathrm{B}$ transcriptional activity was indeed up-regulated in TNF $\alpha$-exposed cells and much more in MITF silenced cells compared with control 501mel melanoma cells (Fig. 5D). Inhibition of the NF-кB signaling pathway through pharmacologic (sulfasalazine) or genetic (IKK2 siRNA and dominantnegative forms of IKK1 and IKK2) approaches prevented activation of the NF- $\mathrm{B}$ reporter gene by siMITF or TNF $\alpha$ (Fig. 5D; Supplemental Fig. 4b). Additionally, both IKK2expressing vector and MITF silencing stimulated activity of the CCL2 promoter that was abrogated by sulfasalazine exposure or IKK2 coknockdown (Fig. 5E). Kinetics experiments revealed an activation of NF- $\kappa \mathrm{B}$ activity between 24 and $36 \mathrm{~h}$ after MITF siRNA transfection, while CCL2 secretion significantly increased between 48 and $72 \mathrm{~h}$ (Supplemental Fig. 5a,b). Put together, these observations demonstrate that melanoma cells undergoing senescence exhibited an enhanced NF-кB activity that controls production of a CCL2-containing secretome and its proinvasive effect.

\section{Secretome formation relies on DNA damage signaling-induced $N F-\kappa B$ activation}

The genotoxic sensor PARP-1 has been involved in the activation of NF-кB (Stilmann et al. 2009). Interestingly, we demonstrated previously that MITF silencing triggers DNA damage (Supplemental Fig. 6; Giuliano et al. 2010). Kinetic studies by Western blot revealed no modification of PARP-1 expression upon MITF silencing (Fig. 6A). However, increased poly-(ADPrybosyl)ation was observed in MITF silenced melanoma cells and H202-treated cells used as positive control (Fig. 6B; Kolthur-Seetharam et al. 2006). MITF silencing-mediated poly-(ADPrybosyl)ation was not affected by sulfasalazine or siIKK2, indicating that PARP-1 acts upstream of NF-кB (Supplemental Fig. 6a). To screen the involvement of PARP-1 in NF- $\mathrm{B}$ activity and secretome formation, we used the PARP inhibitor 3-AB. In presence of 3-AB or sulfasalazine, MITF silencing was no longer able to relocate NF- $\mathrm{B}$ to the nucleus (Fig. 6C) or stimulate the NF- $\mathrm{B}$ transcriptional activity (Fig. 5D). Blockade of NF- $\mathrm{B}$ activity by $3-\mathrm{AB}$ was comparable with that elicited by sulfasalazine, in agreement with these factors functioning in the same pathway (Supple- mental Fig. 6b). Western blot analysis of the corresponding cell extracts revealed that MITF silencing increased IKK2 and p53, which affirmed engagement of the DNA damage/NF-кB axis. IKK2 up-regulation mediated by MITF silencing was abrogated by sulfasalazine (Supplemental Fig. 6c). In contrast, p53 up-regulation was modestly affected by sulfasalazine but was almost completely abrogated by 3-AB.

Similar to MITF depletion, focal staining of 53BP1 was also observed when melanoma cells were exposed to oxidative stress and chemotherapeutic drugs (Supplemental Fig. 7), indicating the presence of DNA damage. Consistent with our hypothesis, the oxidative stress and chemotherapeutic drugs also stimulated the transcriptional activity of NF- $\kappa$ B that was prevented by addition of 3-AB (Fig. 6D). Additionally, blocking PARP-1 or NF-кB signaling pathways prevented, to the same extent, the secretion of CCL2 (Fig. 6E) and invasion, as illustrated by results from Boyden chamber experiments (Fig. 6F). Noteworthy, to avoid the presence of the inhibitors in the CM, which could by themselves affect the invasive properties of naive melanoma cells, the medium was changed before being used in chemotaxis experiments. Together, in melanoma cells, the secretome is governed by a PARP-1 and NF-кB signaling cascade.

\section{PNAS in nonmelanoma cells}

We next wondered whether a similar PNAS could be observed in nonmelanoma cells that have entered a program of senescence. To this aim, we used the model of the MCF7 human breast cancer cells that underwent senescence upon $\mathrm{H}_{2} \mathrm{O}_{2}$, as illustrated by morphological changes, SA- $\beta$-Gal reactivity (Fig. $7 \mathrm{~A})$, and increased expression in the senescence markers p53 and p21 (Fig. 7B). Senescence-like phenotypes of MCF7 in response to $\mathrm{H}_{2} \mathrm{O}_{2}$ were associated with DNA damage induction, as indicated by $\gamma \mathrm{H} 2 \mathrm{AX}$ labeling and stimulation of NF- $\mathrm{B}$ activity shown by the nuclear localization of p65/RELA (Fig. 7C). In agreement with the production of a proinflammatory secretome, the supernatant of senescent MCF7 enhanced the invasion of naive MCF7 cells (Fig. 7D). Although CCL2 was not expected to be the major component of MCF7's secretome, CCL2 measurement was used as a readout of its formation. In this context, senescence entry of MCF7 cells gave rise to CCL2 secretion, which was impaired when MCF7 cells were incubated with 3-AB or sulfasalazine (Fig. 7E). Together, our results reveal that PNAS during cellular senescence is a common mechanism that relies on activation of the DNA damage/NF- $\kappa$ B signaling cascade in both melanoma and nonmelanoma cell lines.

\section{Discussion}

Senescence induction is considered a potential strategy of tumor cell elimination. This is strengthened by the observation that, in humans, senescence induction in human breast cancer and lung carcinoma following chemotherapy is correlated to a favorable outcome 
Ohanna et al.

A

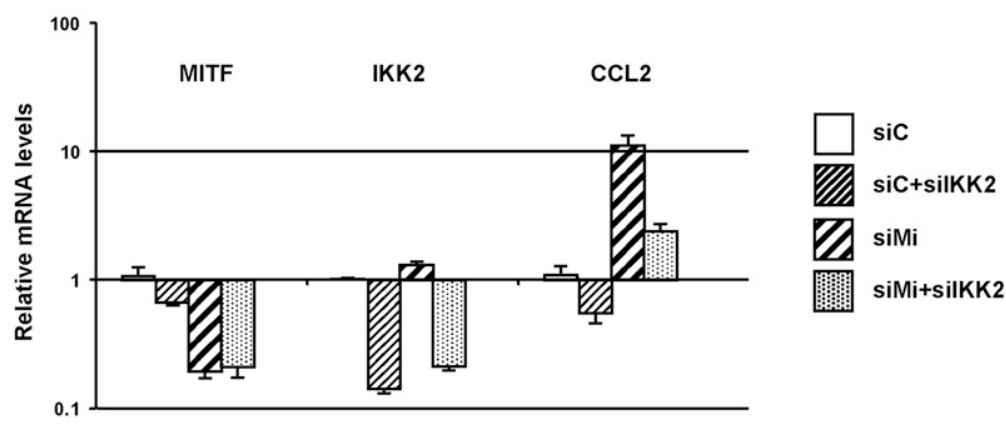

B

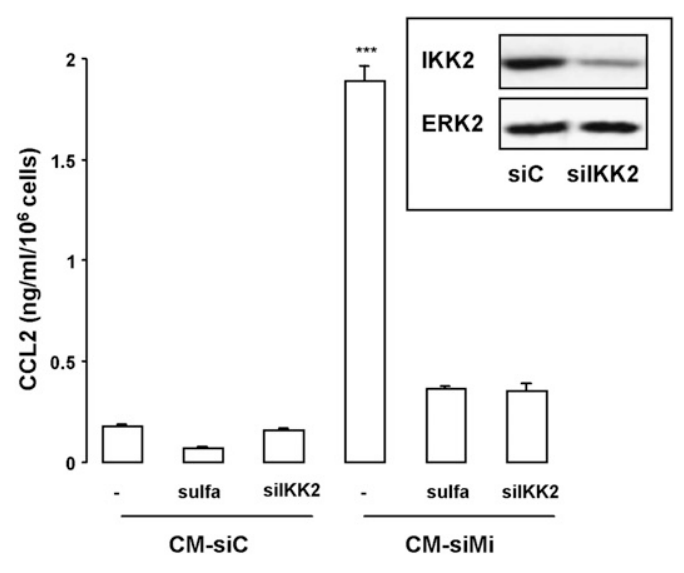

D

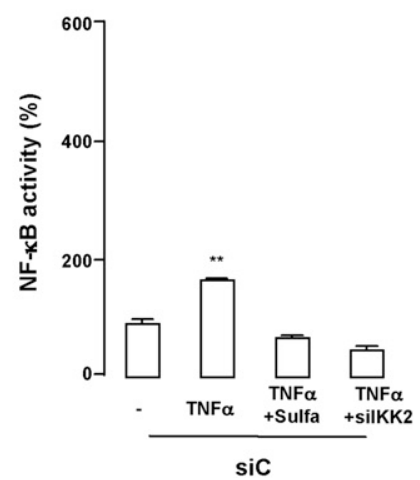

C
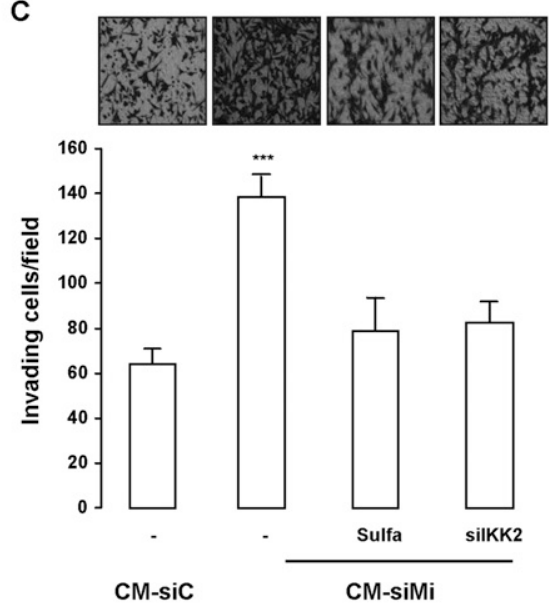

E

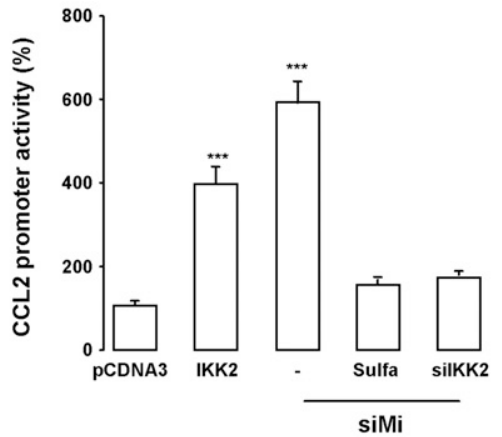

Figure 5. NF- $\mathrm{KB}$ drives CCL2 secretion and proinvasive properties of the secretome. (A) mRNA levels of MITF, IKK2, and CCL2 in $501 \mathrm{mel}$ cells transfected with siC or siMi with or without siIKK2. Bars represent the mean + SD of three independent experiments performed in triplicate. $(B)$ ELISA test of CCL2 secretion levels in the culture medium of $501 \mathrm{mel}$ cells treated or transfected with siC or siMi with or without siIKK2 or exposed to sulfasalazine. Values are expressed as mean + SD and are significantly different from control; $\left(^{\star \star \star}\right) P<0.001$. (Inset) Western blot analysis of IKK2 shows effective IKK2 knockdown by the IKK2 siRNA. $(C)$ The chemotactic effect of the CM of melanoma cell treated as above. The number of nuclei was counted using NIH ImageJ analysis software. Values are expressed as mean $+\mathrm{SD}$. Significantly different from control at $P<0.001\left(^{\star \star \star}\right)$. Representative images are shown. $(D) 501 \mathrm{mel}$ cells were transfected with $\mathrm{siC}$ or siMi and NF-кB luciferase vector. When indicated, cells were co-knocked down for IKK2 (siIKK2) or exposed to the NF-кB inhibitor sulfasalazine (sulfa, $500 \mu \mathrm{M})$ or TNF $\alpha(10 \mathrm{ng} / \mathrm{mL}$ ) for the last $6 \mathrm{~h}$. Ninety-six hours later, the luciferase activity was assessed and normalized to the $\beta$-galactosidase activity. Results are expressed as percent $(\%)+$ SD of the luciferase activity from the control condition. Significantly different from control at $P<0.001\left(^{\star \star \star}\right)$ and $P<0.01\left(^{\star \star}\right)$. (E) 501 mel cells were transfected with empty vector or IKK2-expressing vector or with MITF and/or IKK2 siRNA and the CCL2 promoter luciferase. When indicated, sulfasalazine was added to the siMITF-transfected cells. Luciferase activity was assessed as above. Results are expressed as percent $(\%)+$ SD of the luciferase activity from the control condition. Significantly different from control at $P<0.001\left({ }^{\star \star}\right)$. 
A

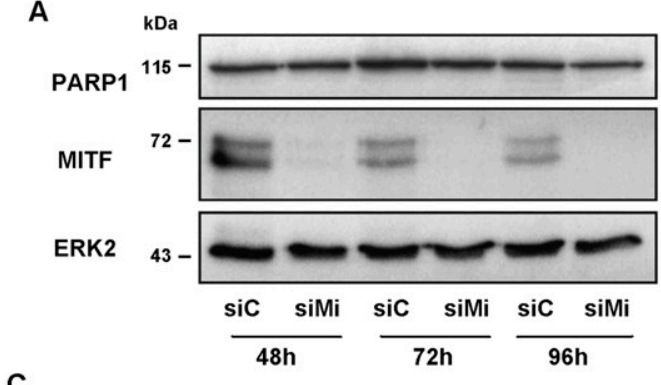

C

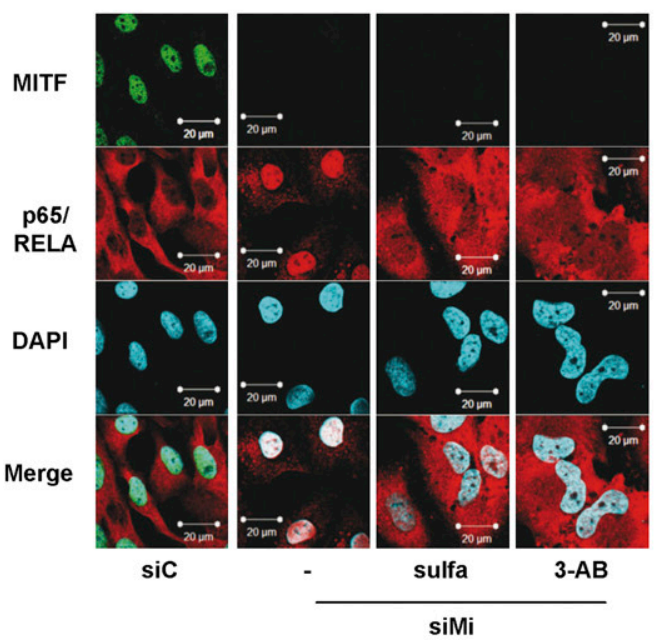

E

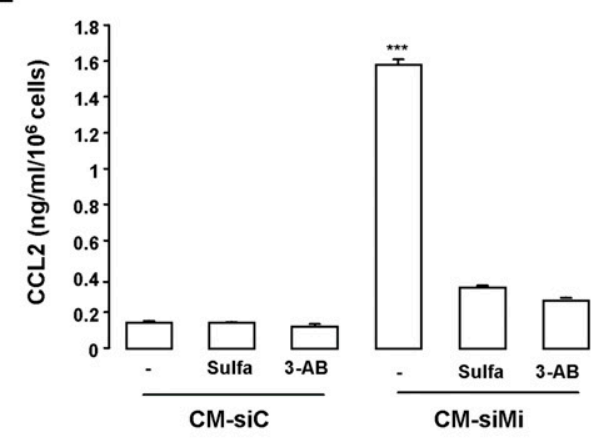

B

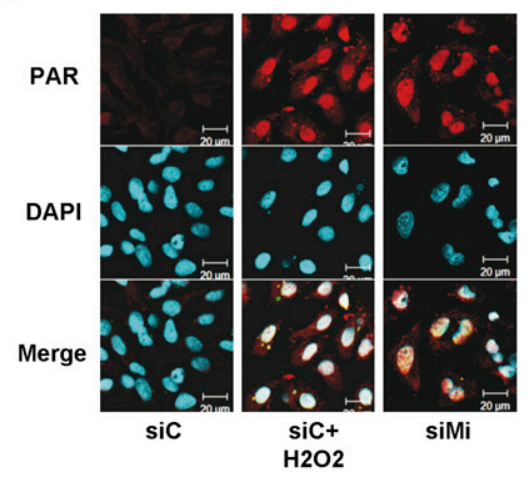

D

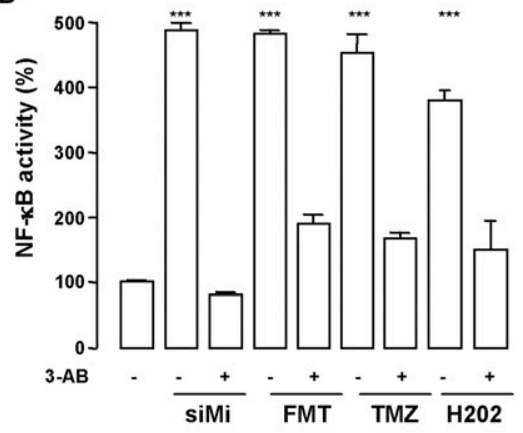

$\mathbf{F}$

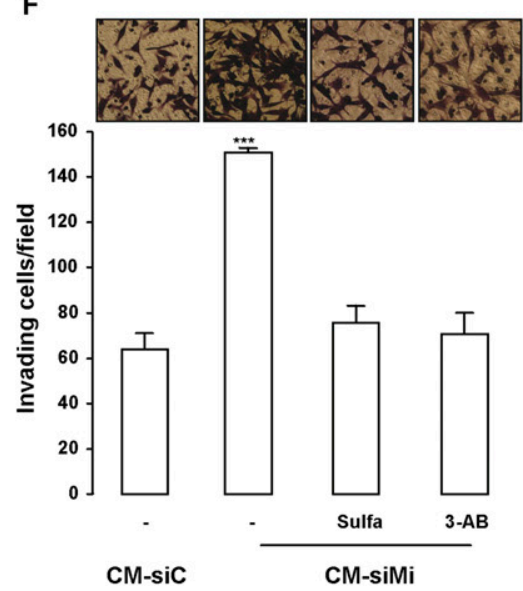

Figure 6. The PARP-1/NF-кB axis plays a key role in the deleterious effect of the secretome. $(A)$ Western blot analysis showing a kinetic experiment of $\mathrm{siC}$ or siMi-transfected $501 \mathrm{mel}$ cell lysates probed with PARP-1, MITF, and ERK2 antibodies. (B) Immunofluorescence with PAR antibody of $501 \mathrm{mel}$ cells transfected for $96 \mathrm{~h}$ with siC or siMi or with siC and exposed to $\mathrm{H}_{2} \mathrm{O}_{2}$ $(100 \mu \mathrm{M}) .(C)$ Immunofluorescent staining with p65/RELA (red) and MITF (green) of 501mel cells transfected with siC or siMi for $96 \mathrm{~h}$

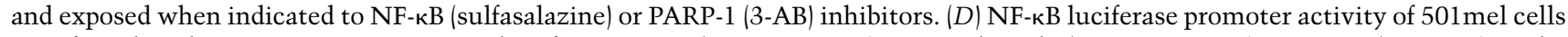
transfected with MITF siRNA or exposed to fotemustine (FMT, $40 \mathrm{mM}$ ), temozolomide (TMZ, $900 \mathrm{nM}$ ), or $\mathrm{H}_{2} \mathrm{O}_{2}(100 \mu \mathrm{M})$ in the presence or absence of $3-\mathrm{AB}(20 \mathrm{mM})$. Results are expressed as percent $(\%)+\mathrm{SD}$ of the luciferase activity from the control condition. $(E)$ CCL2 secretion level was analyzed by ELISA in the CM of $501 \mathrm{mel}$ cells transfected with siC or siMi and exposed to the PARP-1 inhibitor 3-AB $(20 \mathrm{mM})$ or the NF- $\mathrm{kB}$ inhibitor sulfasalazine (Sulfa, $500 \mu \mathrm{M})$ for $96 \mathrm{~h}$. Values are expressed as mean + SD, significantly different from control at $P<0.001\left(^{\star \star \star}\right) .(F) 501 \mathrm{mel}$ cells were transfected with siC or siMi and exposed when indicated to sulfasalazine $(500 \mu \mathrm{M})$ or $3-\mathrm{AB}(20 \mathrm{mM})$. Forty-eight hours after transfection and inhibitor exposure, the medium was changed by DMEM $1 \%$ serum for an additional $48 \mathrm{~h}$. Drug-free CM was next used in chemotaxis experiments with naive 501 mel cells. Cells that had migrated were stained $24 \mathrm{~h}$ later with crystal violet and counted. Values represent mean $+\mathrm{SD}$ of two independent experiments, significantly different from control at $P<0.001\left(^{\star \star \star}\right)$. Representative images are shown. 
A

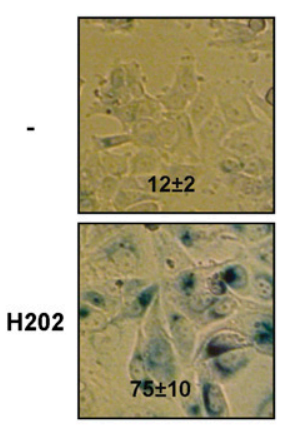

B

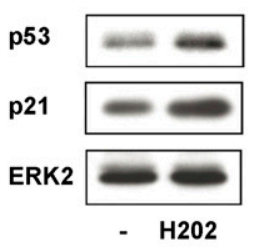

C

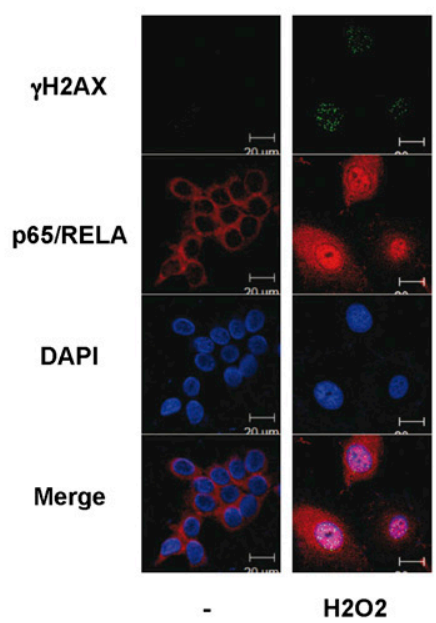

D

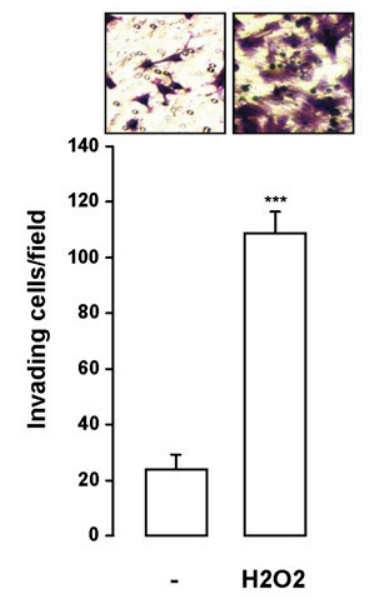

E

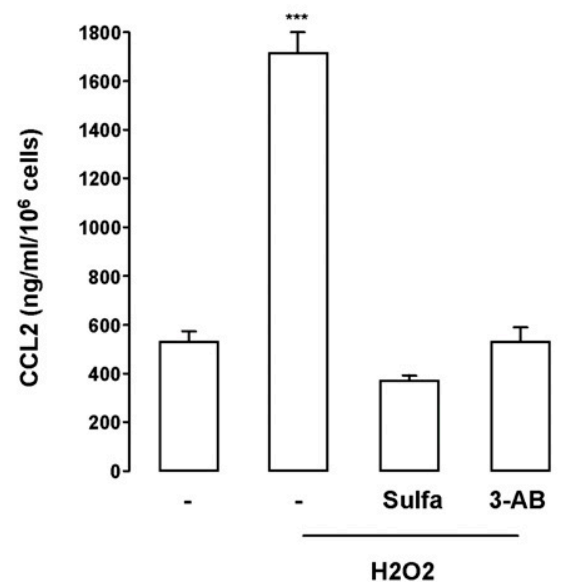

Figure 7. The PARP-1/NF-кB axis is also engaged in the secretome of nonmelanoma cancer cells. $(A)$ MCF7 cells exposed for $96 \mathrm{~h}$ to $\mathrm{H}_{2} \mathrm{O}_{2}(100 \mu \mathrm{M})$ were stained for SA- $\beta$-Gal activity and visualized under phase-contrast microscopy. Numbers on the panels indicate percent of means and standard deviations of SA-b-Gal-positive cells. (B) Western blot analysis with p53, p21, and ERK2 of MCF7 exposed to $\mathrm{H}_{2} \mathrm{O}_{2}$. (C) Immunofluorescent staining with p65/RELA (red) and $\gamma \mathrm{H} 2 \mathrm{AX}$ (green) of MCF7 cells exposed to $\mathrm{H}_{2} \mathrm{O}_{2}$ for 96 h. Nuclei were counterstained with DAPI. (D) CM of control or senescent MCF7 $\left(\mathrm{H}_{2} \mathrm{O}_{2}\right.$ treated) was added to the lower compartment of Boyden chambers to assess their chemotactic activity. Cells that had migrated to the underside of the upper compartment were stained $24 \mathrm{~h}$ later with crystal violet, and the number of nuclei was counted using NIH ImageJ analysis software. Values represent mean + SD of three independent experiments, significantly different from control; $\left(^{\star \star \star}\right) P<0.001$. Representative images are shown. (E) ELISA test of CCL2 level in the CM of control MCF7 or MCF7 incubated with $\mathrm{H}_{2} \mathrm{O}_{2}(100 \mu \mathrm{M})$ and, when indicated, with sulfasalazine (500 $\left.\mu M\right)$ or $3-\mathrm{AB}(20 \mathrm{mM})$. Data are represented as mean $+\mathrm{SD}$, significantly different from control; $\left({ }^{\star \star \star} \_\right) P<0.001$.

(Schmitt et al. 2002; te Poele et al. 2002). However, it has been reported recently that senescent cells develop a secretome containing several proinflammatory factors, which can alter the behavior of nearby cells and represent a barrier for efficient therapy (Coppe et al. 2010). Therefore, understanding the process of senescence in tumor cells should make possible the development of therapeutic approaches with improved therapeutic efficiency.

We provide here the evidence that melanoma cells undergoing a senescence-like program develop a PNAS. Its characterization reveals the presence of several factors previously identified in the senescence-associated secretory profile of other cell types (Coppe et al. 2008; Kuilman et al. 2008; Wajapeyee et al. 2008), with the difference that the CCL2 is a major component of the secretome expressed by senescent melanoma cells. These observations support the idea that the secretome may differ in a cell-dependent context. Importantly, we show that the secretome of senescent melanoma cells and CCL2 enhance the survival and invasiveness of nonsenescent melanoma cells and favor melanoma development in vivo. In support of these results are also the observations that the secretome of senescent melanoma cells promotes a decrease in the levels of E-cadherin and of MITF, two changes that have been associated with melanoma tumor formation and increased invasiveness /Carreira 
et al. 2006; Rodriguez et al. 2008; Cheli et al. 2011). Additionally, the secretome from senescent melanoma cells or recombinant CCL2 induces DNA lesions in naive melanoma cells, although these lesions are not associated with senescence entry (data not shown). This observation is in accord with previous data indicating that DNA lesions correlated with invasiveness (Pinlaor et al. 2005). CCL2 can also trigger systemic levels of DNA damage, impacting on distant tissue homeostasis and participating in the elevated risk of developing other cancers in addition to melanoma, as was proposed previously (Redon et al. 2010). In this context, we found that a neutralizing anti-CCL2 antibodies prevent the proinvasive abilities of this secretome, assuming that CCL2 plays a key role its deleterious effect.

The Merlino group (Zaidi et al. 2011) pointed out recently that CCL2 secretion by melanocytes upon ultraviolet radiation exposure promoted macrophage recruitment to injured skin, and, through INF- $\gamma$ production, they mediated melanocyte survival and immune evasion. Furthermore, CCL2 appears as the most up-regulated secreted factor in MITF silenced cells (Strub et al. 2011) and belongs to pathways identified as candidate drivers of melanoma pathogenesis (Akavia et al. 2010). Hence, CCL2 secretion could be recurrently set up by cells of the melanocyte lineage to control transformation and tumor progression. In accordance with these results, CCL2 silencing was shown previously to reduce melanoma tumor growth, while its overexpression was shown to favor tumorigenesis (Stathopoulos et al. 2008). All of these observations strengthen the idea that CCL2 targeting may enhance anti-melanoma therapies (Zhu et al. 2010).

Notably, the secretome comprises several proinflammatory factors, prompting us to envision involvement of the NF-кB signaling pathway. NF-кB is a key mediator of the proinflammatory response, linking inflammation to cancer development (Lawrence 2009). Additionally, sensors of DNA damage such as the PI3K-related kinase ataxia telangiectasia-mutated (ATM) and PARP-1 have previously identified roles in cellular senescence (WesierskaGadek et al. 2005; d'Adda di Fagagna 2008) and were shown to elicit activation of NF-кB (Li and Karin 1998; Li et al. 2001; Stilmann et al. 2009). However, the biological role of DNA damage-induced NF- $\kappa$ B activation remains poorly understood, and a potential molecular link, if any, between DNA damage, NF- $\kappa \mathrm{B}$, and a senescence-associated secretome has never been demonstrated.

We demonstrate that cellular senescence is associated with an activation of NF- $\mathrm{B}$, and that NF- $\mathrm{B}$, by controlling CCL2 transcription and secretion, mediates the proinvasive capacity of the senescence-associated secretome. This idea is in complete agreement with previous works showing that the IKK/NF-кB complex played a key role in melanomagenesis (Yang et al. 2010), and that NF$\kappa \mathrm{B}$ blockade inhibited the endogenous production of angiogenic and proinflammatory factors and prevents melanoma tumor growth in mice (Yang et al. 2006, 2007).

PARP-1, which detects DNA lesions and drives DNA repair (Dantzer et al. 2006), was also described as a medi- ator of NF- $\mathrm{B}$ activation upon genotoxic stress (Stilmann et al. 2009; Veuger et al. 2009). Inhibition of NF-kB activity and CCL2 secretion by the PARP-1 inhibitor 3$\mathrm{AB}$ points to a PNAS in senescent melanoma cells. The PARP-1 signalosome also contains the DNA damage sensor ATM (Stilmann et al. 2009), which was involved in NF-кB activation following DNA damage (Piret et al. 1999; Huang et al. 2000; Wu et al. 2006). In line with these data and our previous results (Giuliano et al. 2010), we also demonstrate the involvement of ATM in NF-кB activation in melanoma cells undergoing senescence upon MITF depletion or $\mathrm{H}_{2} \mathrm{O}_{2}$ exposure (Supplemental Fig. 8). Our results are in agreement with a direct activation of NF-кB by the DDR, although we cannot rule out that a secondary paracrine feed-forward loop takes place and later triggers a DNA damage-independent NF-кB activation.

Nonmelanoma cells, such as breast cancer cells, also develop a PNAS with a proinvasive effect on naive cells.

Together, we provide the first evidence that expression of a secretory profile during cellular senescence is a common mechanism that relies on activation of the DNA damage/PARP-1/NF- $\mathrm{B}$ signaling cascade (Fig. 8).

We found previously that the DNA damage elicited by MITF silencing promoted p53 stabilization and activation (Giuliano et al. 2010). An interplay between PARP-1 and p53 has been reported (Wieler et al. 2003), and may depend on the type of damage induced to DNA (Valenzuela et al. 2002). We reveal here that PARP-1 inhibition prevents induction of p53 mediated by MITF silencing. On the

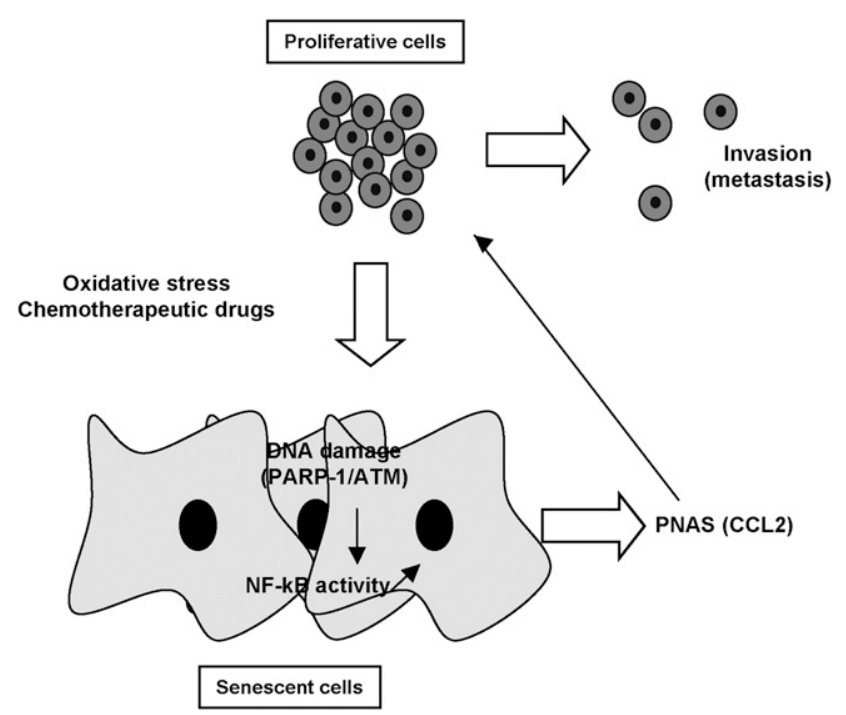

Figure 8. Graphical abstract of the molecular determinants of PNAS' formation and deleterious effects. Chemotherapeutic drugs or oxidative stress induce DNA damage, engagement of the PARP-1/ATM/NF-kB axis, and senescence entry. The senescence phenotypes are associated with the development of a secretome (PNAS) containing, among others, the chemokine CCL2 that enhances invasiveness of melanoma cells that might have escaped the process of senescence. Blocking PARP-1, ATM, or NF-kB prevents the deleterious proinvasive properties of the secretome. 
other hand, NF-кB inhibition only slightly alters p53 levels, indicating that NF- $\mathrm{B}$ and p53 likely act in separate pathways, although a cross-talk between NF- $\mathrm{B}$ and the tumor suppressor p53 has been reported in a different cellular setting (Schneider et al. 2010). The nature of this interplay, if any, remains to be determined in senescent melanoma cells.

p53 functions to impose a transient cell cycle arrest, giving time to the cellular machinery to repair DNA, or triggers a permanent growth arrest such as senescence or cell death when lesions are too severe to be repaired. Besides, NF- $\mathrm{B}$ h has prosurvival function, and its increased activity might bring important survival signals to weakened cells (genotoxically endamaged cells) until DNA is repaired. It has been postulated that the senescenceassociated secretome develops only in response to genotoxic stress of sufficient magnitude to cause senescence (Coppe et al. 2008). This situation matches our results, where MITF silencing, oxidative stress, or chemotherapeutic drugs trigger DNA damage, senescence entry, and secretome formation. In this context, it is conceivable that PNAS allows NF- $\mathrm{B}$ to exert extracellular prosurvival functions to signal the critical situation of injured senescent cells to incompletely damaged neighboring cells to order their proliferation or invasion in different places, thereby ensuring survival of the progeny. Abrogating this signature might prevent the deleterious effects of the PNAS and may thus enhance the therapeutic index.

Temozolomide, fotemustine, or dacarbazine, used against advanced melanoma, have yielded objective response rates of only $10 \%-15 \%$, and most of these are incomplete, with frequent disease relapse, suggesting that their cytostatic effects are compromised and should be improved. PNAS formation could, in part, explain the limited efficacy of these chemotherapeutic treatments. In support of this idea, a study from the group of Bar-Eli (Lev et al. 2003) indicated that dacarbazine unexpectedly induced IL8 and VEGF secretion, causing resistance to this drug. Addition of IL8-neutralizing antibody lowered sensitivity of metastatic melanoma cells to dacarbazine. However, in this latter study, the presence of other proinflammatory molecules was not determined. Consistently, we also found an increased production of IL8 and VEGF, but our results indicate that CCL2 is up-regulated to a much higher level than that of IL8 and VEGF, strengthening the notion that the CCL2 blockade will be even more effective in blocking melanoma progression.

Thus, the combination of temozolomide or fotemustine with PARP-1 inhibitors (several of which are currently being tested in clinical trials) (Helleday et al. 2008) or with NF-кB inhibitors (such as sulfasalazine, currently used in clinics to treat inflammatory bowel diseases) may confer potent anti-melanoma effects by preventing the deleterious effect of prosenescence drugs. PARP-1 inhibition should improve the therapeutic index by hypersensitizing melanoma cells to stimuli that cause DNA damage, such as those caused by MITF suppression, thereby favoring accumulation of excessive DNA lesions incompatible with cell survival and preventing, through abrogation of NF- $\mathrm{B}$ activity, PNAS formation. This is consistent with a recent study showing that PARP-1 inhibition in melanoma and cervical carcinoma lines enhanced in vitro sensitivity to temozolomide (Tentori et al. 2010). These results also provide strong support for the development of NF- $\mathrm{kB}$ or CCL2 blockade strategies in combination with the current anti-melanoma chemotherapies.

Collectively, our findings therefore have important implications for clinics. The identification of the PARP-1/ NF- $\kappa \mathrm{B}$ signaling cascade in the expression of a deleterious secretome in senescent cells opens new avenues for the treatment of cancers.

\section{Materials and methods}

\section{Cell cultures and reagents}

501 mel human melanoma cells and MCF7 human breast cancer cells were grown in DMEM supplemented with $7 \%$ FBS at $37^{\circ} \mathrm{C}$ in a humidified atmosphere containing $5 \% \mathrm{CO}_{2}$. Lipofectamine RNAiMAX and opti-MEM media were purchased from Invitrogen. TNF $\alpha$ and recombinant human CCL2 were from PeproTech, Inc., sulfasalazine and 3-AB were from Sigma Chemical Co., mouse anti-CCL2 was from R\&D Systems, and KU55933 was from Calbiochem. The senescence $\beta$-galactosidase staining kit from Cell Signaling Technology was used to histochemically detect $\beta$-galactosidase activity at $\mathrm{pH} 6$ as reported previously (Giuliano et al. 2010). The percentage of means and standard deviations were derived from counting 100 cells in duplicate plates after $96 \mathrm{~h}$.

\section{Transient transfection of siRNA}

Briefly, a single pulse of $50 \mathrm{nM}$ siRNA was administrated to the cells at $50 \%$ confluency by transfection with $5 \mu \mathrm{L}$ of Lipofectamine RNAiMAX in opti-MEM medium (Invitrogen). Control (siC) and MITF (siMi) siRNAs were described previously (Larribere et al. 2005). When indicated, IKK2 was co-knocked down (IKK2Stealth-RNAi, Invitrogen).

\section{Invasion assay}

Cell invasion was assessed using a modified Boyden chamber assay with $8-\mathrm{mm}$ pore filter inserts for 24-well plates (BD Bioscience). $501 \mathrm{mel}$ cells were seeded on the upper chamber of a Matrigel-coated trans-well and chemoattractants (CM or recombinant molecules) were placed in the lower chamber. Twenty-four hours later, cells adherent to the underside of the filters were fixed with $4 \%$ PFA and stained with $0.4 \%$ crystal violet, and five random fields at $20 \times$ magnification were counted. Results represent the average of triplicate samples from three independent experiments.

\section{Western blot assays}

Western blots were carried out as described previously (Hilmi et al. 2008). Briefly, cell lysates (30 $\mu \mathrm{g}$ ) were separated by SDSPAGE, transferred onto a PVDF membrane, and then exposed to the appropriate antibodies: anti-MITF (Abcam, Ab80651), antiERK2 (Santa Cruz biotechnology, sc-1647 clone D-2), anti-p53 (Santa Cruz Biotechnology, sc-126 clone DO-1), anti-PARP1 (Santa Cruz Biotechnology, sc-1561), and anti-IKK2 (Cell Signaling Technology, Inc., 2370). Horseradish peroxidase-conjugated anti-rabbit or anti-mouse antibodies were from Dakopatts. Proteins were visualized with the ECL system (Amersham). The 
Western blots shown are representative of at least three independent experiments.

\section{mRNA preparation, real-time/qPCR}

mRNA isolation was performed with Trizol (Invitrogen) according to standard procedures. qRT-PCR was carried out with SYBR Green I (Eurogentec) and Multiscribe Reverse Transcriptase (Applied Biosystems) and was monitored by an ABI Prism 7900 Sequence Detection system (Applied Biosystems). Detection of the SB34 gene was used to normalize the results. Primer sequences for each cDNA were designed using either Primer Express software (Applied Biosystems) or qPrimer depot (http:// primerdepot.nci.nih.gov) and are available on request.

\section{Luciferase reporter assays}

501 mel melanoma cells were transiently transfected as described previously using the Lipofectamine reagent (Invitrogen) (Bertolotto et al. 1998). Briefly, cells were transiently transfected with $0.3 \mu \mathrm{g}$ of NF- $\kappa$ B reporter and $0.05 \mu \mathrm{g}$ of pCMVßGal to control the variability in transfection efficiency. The transfection medium was changed $6 \mathrm{~h}$ later, and, when indicated, cells were transfected as described above with $50 \mathrm{nM}$ siC or siMi and/or siIKK2, or were exposed to drugs. Similar experiments were conducted with the CCL2 promoter construct, kindly provided by Dr. S.K. Lin (National Taiwan University, Taiwan). Briefly, CCL2 promoter construct was cotransfected with empty vector or encoding IKK2 vector $(0.1 \mu \mathrm{g})$ or with siMi and/or siIKK2. Cells were assayed for luciferase and $\beta$-galactosidase activities $48 \mathrm{~h}$ later. Transfections were repeated at least three times.

\section{Immunofluorescence studies}

Melanoma cells seeded on glass coverslips in 12-well dishes were transfected with siC or siMi. When indicated, cells were exposed to TNF $\alpha(10 \mathrm{ng} / \mathrm{mL})$. Ninety-six hours later, cells were fixed and permeabilized as described previously (Khaled et al. 2003) before being exposed to anti-MITF (Abcam, Ab80651), anti-p65/RelA (Santa Cruz Biotechnology, sc-372), anti-53BP1 (Bethyl Laboratories, A300-273A), anti- $\gamma \mathrm{H} 2 \mathrm{AX}$ (Millipore, 05-636), anti-PAR (BD Pharmingen, 51-8114KC), and E-cadherin (BD Transduction Laboratories, 610181) antibodies. Cells were washed three times with PBS, and then incubated for $1 \mathrm{~h}$ with 1:1000 dilution antimouse or anti-rabbit Alexa Fluor 488- or Alexa Fluor 594-labeled secondary antibody (Invitrogen) and mounted using Gel/Mount (Biomeda Corp.). Immunofluorescences were examined and photographed with a Zeiss Axiophot microscope equipped with epifluorescence illumination.

\section{ELISA}

CCL2 levels in the supernatant of the different melanoma cell lines, in that of MCF7 cells, or in that of $501 \mathrm{mel}$ cells transfected with siC or siMi for $96 \mathrm{~h}$ in the presence or absence of drugs was quantified by ELISA (R\&D Systems). Results from two independent experiments were normalized to cell number and expressed as nanogram per milliliter per $10^{6}$ cells.

\section{EMSA}

EMSA for NF- $\mathrm{\kappa B}$ was performed as described previously (Imbert et al. 1996). Briefly, extracts prepared from $501 \mathrm{mel}$ cells transfected with siC or siMi or treated with TNF $\alpha$ were incubated with ${ }^{32} \mathrm{P}$-end-labeled synthetic double-stranded oligonucleotides containing the $\kappa \mathrm{B}$-binding site of the immunoglobulin promoter (5'-GATCCAAGGGACTTTCCATG-3') for $20 \mathrm{~min}$ at $37^{\circ} \mathrm{C}$, and the DNA-protein complex formed was separated from free oligonucleotides on $5 \%$ nondenaturating polyacrylamide gels in $0.5 \times$ Tris-Borate EDTA.

\section{Tumor models}

Animal experiments were carried out in accordance with French law and were approved by a local institutional ethical committee. Animals were maintained in a temperature-controlled facility $\left(22^{\circ} \mathrm{C}\right)$ on a 12 -h light/dark cycle and were given free access to food (standard laboratory chow diet from UAR).

Mice were divided randomly into three groups of six mice for the subcutaneous and tail vein xenografts. $501 \mathrm{mel}$ cells were exposed in vitro to the $\mathrm{CM}$ of proliferative or senescent melanoma cells or recombinant CCL2 (100 ng/mL each, $24 \mathrm{~h})$ for $48 \mathrm{~h}$, washed twice with phosphate-buffered saline, and then inoculated subcutaneously/intravenously $\left(4 \times 10^{6}\right.$ cells per mouse $)$ into 6-wk-old female immune-deficient athymic nude FOXN1 ${ }^{n u}$ mice (Harlan Laboratory). The growth tumor curves were determined by measuring the tumor volume using the equation $\mathrm{V}=\left(\mathrm{L} \times \mathrm{W}^{2}\right) / 2$. Mice were killed by $\mathrm{CO}_{2}$ inhalation, and tumors were taken. The lungs were excised, fixed, and serially sectioned. S100 immunostaining (1/100; Abcam) was performed. The number of $501 \mathrm{mel}$ lung colonies was estimated on a section stained with H\&E.

\section{Patient's samples}

Metastatic melanoma specimens were obtained from the Biobank of the Nice CHU hospital, where they were stored after a diagnosis of melanoma. All patients provided informed written consent. Melanoma samples were analyzed by immunohistochemistry on formalin-fixed, paraffin-embedded sections of paired tumor biopsies. The p65/RelA polyclonal antibody (1:750; Santa Cruz Biotechnology) or the MITF monoclonal antibody (1:1000; Abcam) was incubated with the 4- $\mu \mathrm{m}$ tissue section after heat-induced epitope retrieval with citrate buffer (pH 6.0). The samples were incubated with primary antibody for $2 \mathrm{~h}$, followed by incubation with a biotinylated secondary antibody for $30 \mathrm{~min}$. Detection was performed using DAB for $15 \mathrm{~min}$, and the slides were counterstained with hematoxylin/ bluing reagent (Ventana kit, Roche).

\section{Statistical analysis}

Data are presented as averages $\pm \mathrm{SD}$ and were analyzed by student $t$-test using Microsoft Excel. A $P$-value of $0.05\left(\left[{ }^{\star}\right] P<\right.$ $0.05)$ or less $\left(\left[{ }^{\star \star}\right] P<0.01\right.$ and $\left.\left[{ }^{\star \star \star}\right] P<0.001\right)$ was interpreted as indicating statistical significance when comparing experimental and control groups.

\section{Acknowledgments}

We thank Zouhour Neffati for the Gene Ontology analysis. This work was supported by INSERM, the Institut National du Cancer (INCA) grant R08009AP, the "Fondation de France," and the "Association pour la Recherche sur le Cancer" grant 4985. M.O. is a recipient from INCA.

\section{References}

Abdel-Malek ZA, Kadekaro AL, Swope VB. 2010. Stepping up melanocytes to the challenge of UV exposure. Pigment Cell Melanoma Res 23: 171-186. 
Acosta JC, O'Loghlen A, Banito A, Guijarro MV, Augert A, Raguz S, Fumagalli M, Da Costa M, Brown C, Popov N, et al. 2008. Chemokine signaling via the CXCR2 receptor reinforces senescence. Cell 133: 1006-1018.

Akavia UD, Litvin O, Kim J, Sanchez-Garcia F, Kotliar D, Causton HC, Pochanard P, Mozes E, Garraway LA, Pe'er D. 2010. An integrated approach to uncover drivers of cancer. Cell 143: 1005-1017.

Bavik C, Coleman I, Dean JP, Knudsen B, Plymate S, Nelson PS. 2006. The gene expression program of prostate fibroblast senescence modulates neoplastic epithelial cell proliferation through paracrine mechanisms. Cancer Res 66: 794-802.

Bertolotto C, Busca R, Abbe P, Bille K, Aberdam E, Ortonne JP, Ballotti R. 1998. Different cis-acting elements are involved in the regulation of TRP1 and TRP2 promoter activities by cyclic AMP: pivotal role of $M$ boxes (GTCATGTGCT) and of microphthalmia. Mol Cell Biol 18: 694-702.

Carreira S, Goodall J, Denat L, Rodriguez M, Nuciforo P, Hoek KS, Testori A, Larue L, Goding CR. 2006. Mitf regulation of Dial controls melanoma proliferation and invasiveness. Genes Dev 20: 3426-3439.

Cheli Y, Ohanna M, Ballotti R, Bertolotto C. 2010. Fifteen-year quest for microphthalmia-associated transcription factor target genes. Pigment Cell Melanoma Res 23: 27-40.

Cheli Y, Guiliano S, Botton T, Rocchi S, Hofman V, Hofman P, Bahadoran P, Bertolotto C, Ballotti R. 2011. Mitf is the key molecular switch between mouse or human melanoma initiating cells and their differentiated progeny. Oncogene doi: 10.1038/onc.2010.598.

Coppe JP, Patil CK, Rodier F, Sun Y, Munoz DP, Goldstein J, Nelson PS, Desprez PY, Campisi J. 2008. Senescence-associated secretory phenotypes reveal cell-nonautonomous functions of oncogenic RAS and the p53 tumor suppressor. PLoS Biol 6: 2853-2868.

Coppe JP, Desprez PY, Krtolica A, Campisi J. 2010. The senescence-associated secretory phenotype: the dark side of tumor suppression. Annu Rev Pathol 5: 99-118.

d'Adda di Fagagna F. 2008. Living on a break: cellular senescence as a DNA-damage response. Nat Rev Cancer 8: 512-522.

Dantzer F, Ame JC, Schreiber V, Nakamura J, Menissier-de Murcia J, de Murcia G. 2006. Poly(ADP-ribose) polymerase1 activation during DNA damage and repair. Methods Enzymol 409: 493-510.

Davis IJ, Kim JJ, Ozsolak F, Widlund HR, Rozenblatt-Rosen O, Granter SR, Du J, Fletcher JA, Denny CT, Lessnick SL, et al. 2006. Oncogenic MITF dysregulation in clear cell sarcoma: defining the MiT family of human cancers. Cancer Cell 9: 473-484.

Eberle J, Kurbanov BM, Hossini AM, Trefzer U,Fecker LF. 2007. Overcoming apoptosis deficiency of melanoma-hope for new therapeutic approaches. Drug Resist Updat 10: 218-234.

Elledge SJ. 1996. Cell cycle checkpoints: preventing an identity crisis. Science 274: 1664-1672.

Garraway LA, Widlund HR, Rubin MA, Getz G, Berger AJ Ramaswamy S, Beroukhim R, Milner DA, Granter SR, Du J, et al. 2005. Integrative genomic analyses identify MITF as a lineage survival oncogene amplified in malignant melanoma. Nature 436: 117-122.

Giuliano S, Cheli Y, Ohanna M, Bonet C, Beuret L, Bille K, Loubat A, Hofman V, Hofman P, Ponzio G, et al. 2010. Microphthalmia-associated transcription factor controls the DNA damage response and a lineage-specific senescence program in melanomas. Cancer Res 70: 3813-3822.

Giuliano S, Ohanna M, Ballotti R, Bertolotto C. 2011. Advances in melanoma senescence and potential clinical application. Pigment Cell Melanoma Res 24: 295-308.
Hartwell LH, Kastan MB. 1994. Cell cycle control and cancer. Science 266: 1821-1828.

Helleday T, Petermann E, Lundin C, Hodgson B, Sharma RA. 2008. DNA repair pathways as targets for cancer therapy. Nat Rev Cancer 8: 193-204.

Hilmi C, Larribere L, Giuliano S, Bille K, Ortonne JP, Ballotti R, Bertolotto C. 2008. IGF1 promotes resistance to apoptosis in melanoma cells through an increased expression of BCL2, BCL-X(L), and survivin. I Invest Dermatol 128: 1499-1505.

Huang TT, Wuerzberger-Davis SM, Seufzer BJ, Shumway SD, Kurama T, Boothman DA, Miyamoto S. 2000. NF-кB activation by camptothecin. A linkage between nuclear DNA damage and cytoplasmic signaling events. J Biol Chem 275: 9501-9509.

Imbert V, Rupec RA, Livolsi A, Pahl HL, Traenckner EB, Mueller-Dieckmann C, Farahifar D, Rossi B, Auberger P, Baeuerle PA, et al. 1996. Tyrosine phosphorylation of I $\kappa$ B- $\alpha$ activates NF-к B without proteolytic degradation of I $\kappa$ B- $\alpha$. Cell 86: 787-798.

Jane-Valbuena J, Widlund HR, Perner S, Johnson LA, Dibner AC, Lin WM, Baker AC, Nazarian RM, Vijayendran KG, Sellers WR, et al. 2010. An oncogenic role for ETV1 in melanoma. Cancer Res 70: 2075-2084.

Khaled M, Larribere L, Bille K, Ortonne JP, Ballotti R, Bertolotto C. 2003. Microphthalmia associated transcription factor is a target of the phosphatidylinositol-3-kinase pathway. I Invest Dermatol 121: 831-836.

Kolthur-Seetharam U, Dantzer F, McBurney MW, de Murcia G, Sassone-Corsi P. 2006. Control of AIF-mediated cell death by the functional interplay of SIRT1 and PARP-1 in response to DNA damage. Cell Cycle 5: 873-877.

Krtolica A, Parrinello S, Lockett S, Desprez PY, Campisi J. 2001. Senescent fibroblasts promote epithelial cell growth and tumorigenesis: a link between cancer and aging. Proc Natl Acad Sci 98: 12072-12077.

Kuilman T, Peeper DS. 2009. Senescence-messaging secretome: SMS-ing cellular stress. Nat Rev Cancer 9: 81-94.

Kuilman T, Michaloglou C, Vredeveld LC, Douma S, van Doorn R, Desmet CJ, Aarden LA, Mooi WJ, Peeper DS. 2008. Oncogene-induced senescence relayed by an interleukin-dependent inflammatory network. Cell 133: 1019-1031.

Larribere L, Hilmi C, Khaled M, Gaggioli C, Bille K, Auberger P, Ortonne JP, Ballotti R, Bertolotto C. 2005. The cleavage of microphthalmia-associated transcription factor, MITF, by caspases plays an essential role in melanocyte and melanoma cell apoptosis. Genes Dev 19: 1980-1985.

Lawrence T. 2009. The nuclear factor NF-кB pathway in inflammation. Cold Spring Harb Perspect Biol 1: a001651. doi: 10.1101/cshperspect.a001651.

Lev DC, Ruiz M, Mills L, McGary EC, Price JE, Bar-Eli M. 2003. Dacarbazine causes transcriptional up-regulation of interleukin 8 and vascular endothelial growth factor in melanoma cells: a possible escape mechanism from chemotherapy. Mol Cancer Ther 2: 753-763.

Li N, Karin M. 1998. Ionizing radiation and short wavelength UV activate NF-кB through two distinct mechanisms. Proc Natl Acad Sci 95: 13012-13017.

Li N, Banin S, Ouyang H, Li GC, Courtois G, Shiloh Y, Karin M, Rotman G. 2001. ATM is required for IкB kinase (IKKk) activation in response to DNA double strand breaks. I Biol Chem 276: 8898-8903.

Liu D, Hornsby PJ. 2007. Senescent human fibroblasts increase the early growth of xenograft tumors via matrix metalloproteinase secretion. Cancer Res 67: 3117-3126.

Liu F, Fu Y, Meyskens FL Jr. 2009. MiTF regulates cellular response to reactive oxygen species through transcriptional regulation of APE-1/Ref-1. J Invest Dermatol 129: 422-431. 
Matsubara D, Niki T, Ishikawa S, Goto A, Ohara E, Yokomizo T, Heizmann CW, Aburatani $\mathrm{H}$, Moriyama S, Moriyama $\mathrm{H}$, et al. 2005. Differential expression of S100A2 and S100A4 in lung adenocarcinomas: clinicopathological significance, relationship to p53 and identification of their target genes. Cancer Sci 96: 844-857.

Mhaidat NM, Zhang XD, Allen J, Avery-Kiejda KA, Scott RJ, Hersey P. 2007. Temozolomide induces senescence but not apoptosis in human melanoma cells. Br J Cancer 97: 12251233.

Pinlaor S, Sripa B, Ma N, Hiraku Y, Yongvanit P, Wongkham S, Pairojkul C, Bhudhisawasdi V, Oikawa S, Murata M, et al. 2005. Nitrative and oxidative DNA damage in intrahepatic cholangiocarcinoma patients in relation to tumor invasion. World J Gastroenterol 11: 4644-4649.

Piret B, Schoonbroodt S, Piette J. 1999. The ATM protein is required for sustained activation of NF-кB following DNA damage. Oncogene 18: 2261-2271.

Redon CE, Dickey JS, Nakamura AJ, Kareva IG, Naf D, Nowsheen S, Kryston TB, Bonner WM, Georgakilas AG, Sedelnikova OA. 2010. Tumors induce complex DNA damage in distant proliferative tissues in vivo. Proc Natl Acad Sci 107: 1799217997.

Rodriguez M, Aladowicz E, Lanfrancone L, Goding CR. 2008. Tbx3 represses E-cadherin expression and enhances melanoma invasiveness. Cancer Res 68: 7872-7881.

Schmitt CA, Fridman JS, Yang M, Lee S, Baranov E, Hoffman RM, Lowe SW. 2002. A senescence program controlled by p53 and p16INK4a contributes to the outcome of cancer therapy. Cell 109: 335-346.

Schneider G, Henrich A, Greiner G, Wolf V, Lovas A, Wieczorek M, Wagner T, Reichardt S, von Werder A, Schmid RM, et al. 2010. Cross talk between stimulated NF-кB and the tumor suppressor p53. Oncogene 29: 2795-2806.

Serrano M, Lin AW, McCurrach ME, Beach D, Lowe SW. 1997. Oncogenic ras provokes premature cell senescence associated with accumulation of p53 and p16INK4a. Cell 88: 593-602.

Soengas MS, Lowe SW. 2003. Apoptosis and melanoma chemoresistance. Oncogene 22: 3138-3151.

Stathopoulos GT, Psallidas I, Moustaki A, Moschos C, Kollintza A, Karabela S, Porfyridis I, Vassiliou S, Karatza M, Zhou Z, et al. 2008. A central role for tumor-derived monocyte chemoattractant protein-1 in malignant pleural effusion. I Natl Cancer Inst 100: 1464-1476.

Steinert S, Shay JW, Wright WE. 2000. Transient expression of human telomerase extends the life span of normal human fibroblasts. Biochem Biophys Res Commun 273: 1095-1098.

Stilmann M, Hinz M, Arslan SC, Zimmer A, Schreiber V, Scheidereit C. 2009. A nuclear poly(ADP-ribose)-dependent signalosome confers DNA damage-induced IкB kinase activation. Mol Cell 36: 365-378.

Strub T, Giuliano S, Ye T, Bonet C, Keime C, Kobi D, Le Gras S, Cormont M, Ballotti R, Bertolotto C, et al. 2011. Essential role of microphthalmia transcription factor for DNA replication, mitosis and genomic stability in melanoma. Oncogene doi: 10.1038/onc.2010.612.

Tentori L, Muzi A, Dorio AS, Scarsella M, Leonetti C, Shah GM, $\mathrm{Xu} \mathrm{W,} \mathrm{Camaioni} \mathrm{E,} \mathrm{Gold} \mathrm{B,} \mathrm{Pellicciari} \mathrm{R,} \mathrm{et} \mathrm{al.} 2010$. Pharmacological inhibition of poly(ADP-ribose) polymerase (PARP) activity in PARP-1 silenced tumour cells increases chemosensitivity to temozolomide and to a N3-adenine selective methylating agent. Curr Cancer Drug Targets 10: 368-383.

te Poele RH, Okorokov AL, Jardine L, Cummings J, Joel SP. 2002. DNA damage is able to induce senescence in tumor cells in vitro and in vivo. Cancer Res 62: 1876-1883.
Valenzuela MT, Guerrero R, Nunez MI, Ruiz De Almodovar JM, Sarker M, de Murcia G, Oliver FJ. 2002. PARP-1 modifies the effectiveness of p53-mediated DNA damage response. Oncogene 21: 1108-1116.

Vance KW, Carreira S, Brosch G, Goding CR. 2005. Tbx2 is overexpressed and plays an important role in maintaining proliferation and suppression of senescence in melanomas. Cancer Res 65: 2260-2268.

Veuger SJ, Hunter JE, Durkacz BW. 2009. Ionizing radiationinduced NF- $\mathrm{KB}$ activation requires PARP-1 function to confer radioresistance. Oncogene 28: 832-842.

Wajapeyee N, Serra RW, Zhu X, Mahalingam M, Green MR. 2008. Oncogenic BRAF induces senescence and apoptosis through pathways mediated by the secreted protein IGFBP7. Cell 132: 363-374.

Wellbrock C, Rana S, Paterson H, Pickersgill H, Brummelkamp T, Marais R. 2008. Oncogenic BRAF regulates melanoma proliferation through the lineage specific factor MITF. PLOS ONE 3: e2734. doi: 10.1371/journal.pone.0002734.

Wesierska-Gadek J, Ranftler C, Schmid G. 2005. Physiological ageing: role of p53 and PARP-1 tumor suppressors in the regulation of terminal senescence. I Physiol Pharmacol 56: 77-88.

Wieler S, Gagne JP, Vaziri H, Poirier GG, Benchimol S. 2003. Poly(ADP-ribose) polymerase-1 is a positive regulator of the p53-mediated G1 arrest response following ionizing radiation. J Biol Chem 278: 18914-18921.

Wu ZH, Shi Y, Tibbetts RS, Miyamoto S. 2006. Molecular linkage between the kinase ATM and NF-кB signaling in response to genotoxic stimuli. Science 311: 1141-1146.

Yang J, Amiri KI, Burke JR, Schmid JA, Richmond A. 2006. BMS345541 targets inhibitor of $\kappa \mathrm{B}$ kinase and induces apoptosis in melanoma: involvement of nuclear factor $\mathrm{\kappa B}$ and mitochondria pathways. Clin Cancer Res 12: 950-960.

Yang J, Pan WH, Clawson GA, Richmond A. 2007. Systemic targeting inhibitor of $\mathrm{\kappa B}$ kinase inhibits melanoma tumor growth. Cancer Res 67: 3127-3134.

Yang J, Splittgerber R, Yull FE, Kantrow S, Ayers GD, Karin M, Richmond A. 2010. Conditional ablation of Ikkb inhibits melanoma tumor development in mice. I Clin Invest 120: 2563-2574.

Zaidi MR, Davis S, Noonan FP, Graff-Cherry C, Hawley TS, Walker RL, Feigenbaum L, Fuchs E, Lyakh L, Young HA, et al. 2011. Interferon- $\gamma$ links ultraviolet radiation to melanomagenesis in mice. Nature 469: 548-553.

Zhu X, Fujita M, Snyder LA, Okada H. 2010. Systemic delivery of neutralizing antibody targeting CCL2 for glioma therapy. J Neurooncol doi: 10.1007/s11060-00-10-0473-5.

Zhuang D, Mannava S, Grachtchouk V, Tang WH, Patil S, Wawrzyniak JA, Berman AE, Giordano TJ, Prochownik EV, Soengas MS, et al. 2008. C-MYC overexpression is required for continuous suppression of oncogene-induced senescence in melanoma cells. Oncogene 27: 6623-6634. 


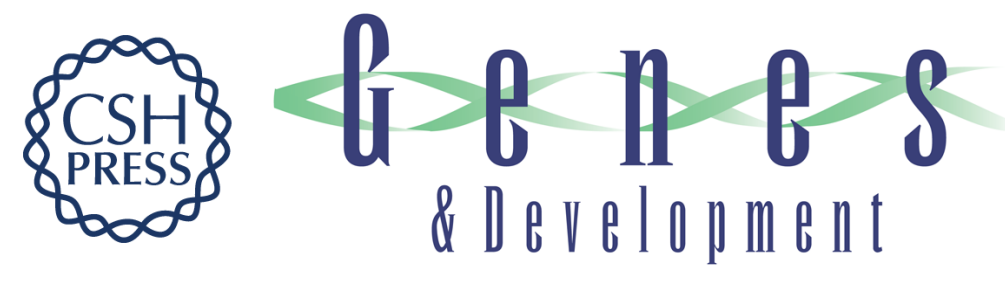

\section{Senescent cells develop a PARP-1 and nuclear factor- $\mathrm{kB}$-associated secretome (PNAS)}

Mickaël Ohanna, Sandy Giuliano, Caroline Bonet, et al.

Genes Dev. 2011, 25: originally published online June 6, 2011

Access the most recent version at doi:10.1101/gad.625811

\section{Supplemental http://genesdev.cshlp.org/content/suppl/2011/06/02/gad.625811.DC1 Material}

References This article cites 63 articles, 23 of which can be accessed free at: http://genesdev.cshlp.org/content/25/12/1245.full.html\#ref-list-1

\section{License}

Email Alerting

Receive free email alerts when new articles cite this article - sign up in the box at the top Service

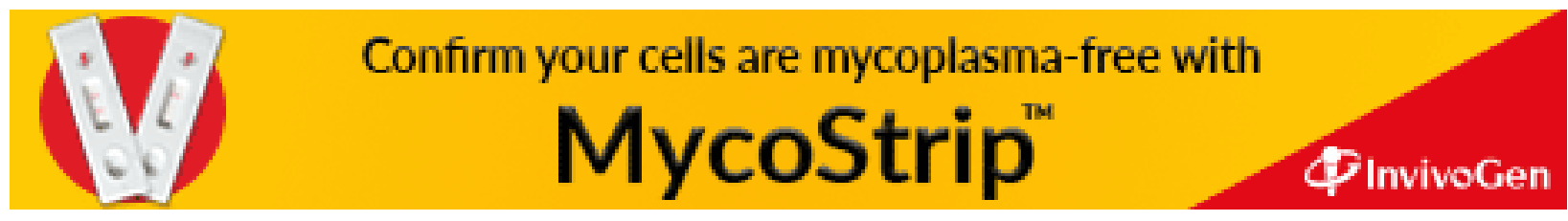

